\title{
IV. Murat Dönemi Osmanlı Seferlerinde Konar- Göçerlerin Et Temini ve Taşımacılık Hususundaki Rolleri
}

\section{Role of Nomads in Meat Supply and Transportation in the Ottoman Campaigns of Murat IV Period}

\author{
Süleyman POLAT ${ }^{1}$
}

'Sorumlu yazar/Corresponding author: Süleyman Polat (Doç. Dr.)

Ankara Hacı Bayram Veli Üniversitesi, Edebiyat Fakültesi, Tarih Bölümü, Türkiye

E-posta: suleymanpolat_@hotmail.com

ORCID: 0000-0002-1939-7293

Başvuru/Submitted: 03.06 .2020 Revizyon Talebi/Revision Requested: 29.07.2020

Son Revizyon/Last Revision Received: 14.09.2020

Kabul/Accepted: 03.10.2020

Online Yayın/Published Online: 25.11.2020

Atıf/Citation: Polat, Suleyman. "IV. Murat Dönemi Osmanlı Seferlerinde Konar-Göçerlerin Et Temini ve Taşımacılık Hususundaki Rolleri." Türkiyat Mecmuası-Journal of Turkology 30, 2 (2020): 671-698.

https://doi.org/10.26650/iuturkiyat.747348 öz

Bilindiği üzere Osmanlı Devleti'nin kuruluşunu sağlayan en temel etkenlerden birisi konar-göçer Türkmenlerin sağladığı katkıydı. Nitekim konar-göçer Türkmenler Osmanlı Devleti'nin kuruluş aşamasında sağladıkları dinamizmin yanında, askerî çatışmalara verdikleri destek ile de yeni devletin oluşumunda etkili olmuştu. Ancak devletin kuruluş sürecinin tamamlanması, merkez, taşra ve askerî teşkilatının gelişmesiyle beraber konar-göçer grupların askerî sahada üstlendikleri rol de değişmişti. Osmanlı Devleti'nin ilk zamanlarındaki durumunun aksine konar-göçerler savaşın merkezindeki rollerini kaybetmişse de ilerleyen dönemlerdeki Osmanlı savaşlarında üstlendikleri rolleri değişerek devam etmişti. Bu çalışmada merkeziyetçi yapının oluşup devlet teşkilatının gelişmesine bağlı olarak, XVII. yüzyıldaki örnekler dâhilinde Osmanlı Devleti'nin askerî faaliyetleri içerisinde konar-göçerlerin savaşlardaki değişen rolü ele alınmaktadır. Buna göre konar-göçerlerin beyliğin kuruluş sürecinde verdikleri askerî destekten, zaman içerisinde üretim yapan ve vergilerini ödeyen tebaaya dönüşmeleriyle birlikte, savaşlarda üstlendikleri aynî yükümlülüklere yer verilmiştir. Bu kapsamda incelenen sefer örneklerinde, konar-göçerlere tarh edilen aynî vegiler ve bu cemaatlerden yapılan koyun satın alımlarıyla ordunun iaşe meselesine sağladıkları katkıdan bahsedilmiştir. Yine ordunun taşıma işinde kullanılmak amacıyla konar-göçer cemaatlerden hangi yöntemlerle, ne şekilde yük hayvanlarının temin edildiği incelenmiştir. Tüm bu süreçte konargöçerlerin yükümlülüklerini hangi ölçüde yerine getirdiği çalışmanın bir diğer odak noktasını oluşturmuştur.

Anahtar kelimeler: Konar-göçerler, Sefer Organizasyonu, IV. Murat, Bağdat, Koyun ve Deve Tedariki

\section{ABSTRACT}

As it is known, one of the main factors, which facilitated the establishment of the Ottoman Empire, was the contribution of nomadic Turkmens. These nomadic Turkmens were influential in the formation of the Ottoman State with their support in military conflicts as well as their dynamism in the foundation phase of the new state. However, the role of nomadic groups in the military field changed with the completion of the foundation process and development of central, provincial and military organisation. Although the nomads lost their central role in war, contrary to the earlier periods of the Ottoman State, their role in the Ottoman wars in later periods transformed and continued. This study discusses 
the changing role of nomads in wars as part of the military activities of the Ottomans depending on the formation of a centralist structure and development of state organisation, with examples from the 17th century. It indicates the real obligations of nomads in wars as part of their new status in the military organisation, with their transformation from a people who provided support to principality forces to subjects who engaged in production and paid tax over time. In the campaign examples examined within this scope, this study also discusses the in-kind taxes levied on nomads and their contribution to the subsistence of the army in terms of purchasing sheep from these communities. In addition, this study examines the methods by means of which animals were obtained from nomadic communities to be used in military transportation duties. The extent to which nomads fulfilled their obligations in this whole process constitutes another focus of the study.

Keywords: Nomads, Campaigns, Murat IV, Baghdad, Sheep and Camel Supply

\section{EXTENDED ABSTRACT}

The Ottoman Empire conducted its military activities, particularly during the course of foundation of the Beylic, with the forces provided by the nomadic Turkmen groups. However, formation of a state organisation upon expansion of the borders also led to a change in military structure. Sultan's household soldiers at the headquarters and the soldiers deployed under the manorial system within provincial organisation changed the role of nomadic communities in wars, as well. The nomads, who had once been groups fighting in the frontlines in the wars, turned into citizens who produced, paid tax and undertook the tasks assigned to them during the time of war. Under these new conditions, the role of nomads during Ottoman wars was to contribute through the animals they raised and provide service. This service involved satisfying the need for meat of the army with the sheep they fed, and providing logistics support by selling their camels or transporting the loads of the army.

One of the basic principles of the Ottoman campaign organisations was, as far as possible, to supply the food and other ammunition required by the army from the people in and around the expedited region. Accordingly, considering the living areas of the nomadic communities like Bozulus, Danişmendlü, Türkmen-i Halep and Yeni-il during the second half of the XVI century and the first half of the XVII century, the roles played by the said groups multiplied during the campaigns of the Ottoman Empire towards the east. Particularly, during the periods when the battle between the Ottoman Empire and Safavid Dynasty arose, such as in the era of Murat IV, demands from the nomadic rayah in the region increased. During the era of Murat IV, the Campaign of Hüsrev Paşa to Baghdad, the Revan Campaign participated in by the Sultan in person and the Baghdad Campaign in 1638, were good examples to observe contributions of the nomadic communities to Ottoman campaigns. Thus, this study focused on the contribution of nomads to the campaigns towards the east during the era of Murat IV.

One of the most important items of food for the Ottoman Campaign organisations was meat. It was the most critical product in terms of the supplying process as it was required to be supplied fresh and consumed before spoilage within the time frame of the conditions. In the Ottoman Empire, the need for meat was substantially satisfied by means of the sheep raised by the nomads. This was the case during organisation of the campaigns, as well. The sheep 
required for the meat needs of the soldiers was supplied through the extraordinary taxes and purchases, which had been rendered a liability. Within the frame of the campaigns mentioned in the details of the study, how much meat was supplied from which nomadic community was demonstrated with examples of documents. Moreover, how much of the quantity of sheep demanded from the nomads during the Revan and Baghdad campaigns was also collected. In doing so, it was aimed to find out which nomad, by name, fulfilled his liability to what extent. In addition, it was also aimed to determine the setbacks and question the reasons hereof.

Transportation in Ottoman campaign organisations during the early modern period was largely performed by means of camels. The direction of the campaigns, east, west, north or south, had not changed this. Thus, the leading camel producers within the Ottoman society were the nomads. Naturally, the first group to consult for supplying camels during campaign organisations was the nomadic people. The camels were supplied by the nomads in two ways. The first one was supplying camels by demanding the avarız, an extraordinary tax, in kind. The other one was, as in the supply of sheep, purchasing the camels in exchange for a set price. In this study, by which methods and in what quantities camels were demanded from the nomadic people during the Revan and Baghdad campaigns were put forward. Furthermore, to what extent those demands were satisfied by the related people was determined. In addition, the tasks regarding logistics support to the army undertaken by the nomadic groups were examined. In the light of the campaigns examined accordingly, the distances along which the military ammunition were transported and the price paid in consideration were found. Moreover, data relating to the financing of the said transportation were given. Finally, all these data obtained from the archives were subjected to a general evaluation in the assessment part of the study. 


\section{Giriş}

Bilindiği üzere Moğol baskıları sebebiyle Anadolu'ya göç eden Türkmenlerden olan Osmanlılar yerleştikleri Anadolu'nun Batı ucunda kısa zaman içerisinde kayda değer bir siyasi teşekkül meydana getirmişlerdi. Osmanlı Beyliği’nin siyasi yapılanma sürecinde dayandığı en temel faktör "savaşçı bölükler" halinde teşkil edilmiş aşiret kuvvetleriydi. Nitekim konargöçer unsurların yaşam biçiminin ve boy teşkilatının ortaya çıkardığı bir özellik olan "savaşçı bölükler" sayesinde, tarihte Selçuklu, Harizmşah, Akkoyunlu, Karakoyunlu, Safevi gibi pek çok Türk devleti kurulmuştu'. Benzer bir biçimde Osmanlı Devleti'nin kuruluş sürecinde de konar-göçer Türkmenlerin² sağladığı kuvvetler askerî teşkilatın ana unsurunu oluşturmuş, dolayısıyla Türkmenler bizzat askerî faaliyetlerin içerisinde yer almışlardı. Öyle ki Osmanlı Beyliği'nin ilk büyük ve ciddi çarpışması olan Bafeus muharebesinde³, Osman Gazi’ye bağlı kuvvetlerin hemen hemen hepsi atlı konar-göçer Türkmenlerden oluşmaktaydı. Bu savaşta mevcut asker potansiyeli dikkate alınarak Bizans'ın piyade ağılıklı kuvvetlerine karşı klasik Türkmen savaş taktikleri uygulanmış ve savaş kazanılmışt14.

Bafeus savaşından yaklaşık otuz sene sonra Orhan Gazi döneminde yine Bizans ile vuku bulan Pelekanon (Eskihisar) savaşı da Türkmen kuvvetlerinden oluşan atılıarın ağırlıkta olduğu bir güçle kazanılmıştı. Ancak bu savaş Osmanlı Devleti'nde ordunun merkezinde hafif zırhlı süvarilerden oluşan birliklere dayanan klasik Türkmen savaş geleneğinden kopuşun başlayıp, ağırlıklı olarak piyadelerin kullanılacağı bir savaş sisteminin habercisiydi ${ }^{5}$. Bununla beraber bahsedilen değişim tedrici suretle yaşanırken XIV ve XV. yüzyıllarda Türkmen menşeli kuvvetler ordunun sayı bazında büyük kısmını oluşturmaktaydı $1^{6}$. I. Kosova savaşında ordunun merkezinde I. Murat'la beraber yaya ve yeniçerilerden oluşan askerler bulunmakla birlikte, sağ ve sol kanatta Türkmen kökenli kuvvetler yer almıştı. Özellikle savaş planının önemli bir parçasını akıncı beylerinden Evrenos Bey üstlenmiş̧i. Yine sağ kanatta Rumeli’nin önemli akıncı beyleri yer almışt ${ }^{7}$. XV. yüzyıl ortalarına gelindiğindeyse Batı'daki rakiplerin güçlenmesi ve

1 Feridun Emecen, Osmanlı Klasik Çağında Savaş (İstanbul: Timaş Yayınları, 2010), 15-16.

2 "Konar-göçer" ifadesi temel yaşam ihtiyaçlarını hayvan üretimine bağlamış, bu nedenle hareket hâlinde bir hayatı benimseyen toplulukları ifade etmek için kullanılan bir tabirdi. Konar-göçerlik İslamiyet öncesi ve sonrasında Türkmen grupları tarafından çoğunlukla benimsenmiş bir yaşam biçimiydi. Osmanlı kaynaklarında konar-göçerler için "göçer", "haymâne taifesi”, "göçebe taifesi”, "yörük”, "yörükân”, "Türkmen" "Türkmanan", "cemaat-i Türkman”, "aşiret” gibi ifadeler kullanılmıştı. Bkz. İlhan Şahin, Osmanlı Döneminde Konar-Göçerler (İstanbul: Eren Yayınları, 2006), 158; Tufan Gündüz, "Konar-göçer”, TDV İslam Ansiklopedisi, c. 26, (İstanbul: TDV Yayınları, 2002), 161-163. Bu nedenle çalışmada, "konar-göçer" ifadesinin yanında "konar-göçer cemaat(ler)", "konar-göçer reaya" ya da "tebaa", "konar-göçer Türkmen(ler)", "konar-göçer aşiret(ler)" gibi anlatımın yapıldı̆̆ı yerde kullanılan kaynağa bağlı olarak, kaynakta geçen tabirler kullanılmıştır.

3 Bu savaşın süreciyle alakalı ayrıntılı bilgi için bkz. Halil İnalcık “Osman Gazi’nin İznik (Nicaea) Kuşatması ve Bafeus Savaşı”, Söğüt'ten İstanbul'a Osmanlı Devleti’nin Kuruluşu Üzerine Tartışmalar, Der. Oktay ÖzelMehmet Öz, (Ankara: İmge Yayınları, 2005), 301-339.

4 Emecen, Osmanlı Klasik Çă̆ında Savaş, 17-18.

5 Emecen, Osmanlı Klasik Çă̆ında Savaş, 21.

6 Bu süreci anlatan bir başka kaynak için bkz. Abdullah Saydam, "Sultanın Özel Statüye Sahip Tebaası: KonarGöçerler”, SDÜ Fen Edebiyat Fakültesi Sosyal Bilimler Dergisi 20 (2009), 12-14.

7 Emecen, Osmanlı Klasik Çă̆ında Savaş, 119-120. 
bu güçlü rakiplerin daha modern silahlarla mücadele vermesi, Türkmenlerden teşekkül edilen ve geleneksel Türkmen savaş teçhizatıyla teşkil edilmiş savaşan grupları olumsuz etkilemeye başlamıştı ${ }^{8}$. Nitekim II. Kosova Savaşı'nda ateşli silahları kullanan Yanko’ya karşı savaşın kazanılmasında kritik rolü üstlenen askerî grup, ordunun merkezinde bulunan yeniçeriler ve azaplardıํ. Bu savaş aynı zamanda XIV. yüzyılın ikinci yarısından XV. yüzyılın ortalarına kadar Osmanlı genişlemesinde önemli rol oynayan akıncı beylerinin ve Türkmenlerden oluşan akıncı kuvvetlerinin ateşli silahlar karşısında aksamaya başladıklarını da göstermişti ${ }^{10}$. Bu durumun en çarpıcı etkisi ise, Türkmenlerden oluşan savaşçı grupların tedrici suretle geri plana düşmesiydi. Öyle ki Fatih Sultan Mehmet'in merkezi devlet teşkilatını oturtması ve kapıkullarına dayalı ateşli silahları kullanan askerî sınıfı genişletmesi ve geliştirmesiyle Rumeli’nde gaza liderliğini yürüten akıncılar önemini kaybetmişti. Her ne kadar varlığını XVII. yüzyıla kadar sürdürseler de XVI. yüzyılın başlarından itibaren bu grubun savaşlardaki etkinlikleri iyice azalmış, artık sadece batıdaki değil, doğudaki seferlerde de kendilerine biçilen daha küçük ölçekli görevleri ifa etmeye başlamışlard $1^{11}$.

Anlaşılacağı üzere zaman içerisinde değişen askerî koşullar ve yeni fetihler askerî teşkilatın da değişimini kaçınılmaz kılmış, bu çerçevede devletin ihtiyaçlarını karşılayacak, yeni fethedilen yerleri koruyacak ve fetihlerin devamını sağlayacak, bir askerî teşkilat oluşturulmuştu. Tımar teşkilatının Osmanlı taşra teşkilatı içerisinde oturtulması, kapıkulu askerleri adı verilen düzenli profesyonel ordunun oluşturulması ve sayılarının sürekli artması zaman içerisinde konargöçerler seferlerdeki savaşçı rolünü değiştirmişti. Nitekim XVI. yüzyıldan itibaren diğer Osmanlı tebaası gibi Türkmenlere seferlerde biçilen görev, hangi işle meşgulse hangi üretimi yapıyorsa o işi sürdürmeleri ve savaş esnasında ordunun her türlü ihtiyacını karşılayarak destek olmalarıydı. Öyle ki bu çalışmada Osmanlı Devleti'nin devlet teşkilatını oluşturmasının akabinde, konar-göçer gruplara verilen yeni roller çerçevesinde bu grupların savaşlara katkısı ele alınmıştır. Bununla beraber bu çalışmanın odağında bulunan konar-göçer cemaatler birçok akademik çalışmanın inceleme konusunu oluşturmuştur. Bu çalışmalar başta tahrir defterleri olmak üzere arşiv kaynakları temel alınarak hazırlanmıştır. Söz konusu araştırmaların odak noktasını konar-göçerlerin nüfusu, yaşam alanları, iktisadi sahadaki faaliyetleri, olağan vergi düzeni içerisindeki hazineye katkıları, merkez teşkilatıyla olan ilişkileri gibi konular

8 Özellikle savaşan birliklerin değişimiyle konar-göçerler geri hizmette kullanılmaya başlanmıştı. Sadullah Gülten, XVI. Yüzyılda Batı Anadolu'da Yörükler (Basılmamış Doktora Tezi, Gazi Üniversitesi Sosyal Bilimler Enstitüsü, 2008), 63.

9 Feridun Emecen, "Kosova Savaşları”, TDV İslam Ansiklopedisi, c. 26, (Ankara: TDV Yayınları, 2002), 223.

10 Halil İnalcık, Kuruluş Dönemi Osmanlı Sultanları (İstanbul: İsam Yayınları, 2010), 154.

11 Abdulkadir Özcan, "Akıncı", TDV İslam Ansiklopedisi, c. 2, (İstanbul: TDV Yayınları, 1989), 250; Gabor Agaston, "Savaş", TDV İslam Ansiklopedisi, c. 36, (İstanbul: TDV Yayınları, 2009), 197. 
oluşturmuştur $^{12}$. Bunun yanında konar-göçer aşiretlerin farklı tarihlerdeki iskânı üzerine yapılmış çalışmalar da mevcuttur ${ }^{13}$. Ancak bu çalışmalarda konar-göçer cemaatlerin savaş gibi olağanüstü zamanlarda hangi koşullarda nasıl roller üstlendiklerine sistemli bir biçimde değinilmemişti ${ }^{14}$. Bunun yanında sefer organizasyonu çerçevesinde yapılmış çalışmalarda da benzer durum söz konusuydu. Bu tür çalışmaların odak noktası ordunun sefere hazırlığı, menzil yerleri, ordunun yürüyüşü, kışlak organizasyonu, seferin finansmanı gibi başlıklar oluşturmuştur ${ }^{15}$. Bu tarz çalışmalarda nakliye ve iaşe organizasyonu faslında kısmen konar-göçer cemaatlerin katkılarından bahsedilmiştir ${ }^{16}$. Lakin yapılan çalışmaların kurgusu doğrultusunda konar-göçerlerin sefere katkısı muhtelif başlıklar içerisinde dağılmış vaziyetteydi. Dolayısıyla bir bütünlük arz etmemektedir. Nitekim bu çalışmanın amacı Osmanlı taşra toplumunun önemli bir parçası olan konar-göçerlerin XVII. yüzyılın ortalarında vuku bulan seferlerdeki rolünü daha sistematik bir biçimde ortaya koymaktır. Bu doğrultuda IV. Murat devrinde düzenlenen üç doğu seferi incelemeye konu olmuştur. Özellikle sefer organizasyonlarıyla ilgili ayrıntılı bilgilerin bulunduğu, Hüsrev Paşa'nın Bağdat (1630), 1635 Revan ve 1638 Bağdat seferleri esnasında, sefer bölgesinde bulunan konar-göçer grupların organizasyonlarda aldıkları roller üzerinde durulacaktır.

12 Bu tarz çalışmalara örnek olarak bkz. Tayyib Gökbilgin, Rumelide Yörükler, Tatarlar ve Evlâd-ı Fâtihân (İstanbul: İstanbul Üniversitesi Edebiyat Fakültesi Yayınları, 1957); Şahin, Osmanlı Döneminde Konar-Göçerler; Sadullah Gülten, XVI. Yüzyılda Batı Anadolu'da Yörükler; Yusuf Halaçoğlu, Anadolu'da Aşiretler Cemaatler ve Oymaklar (1453-1650), 1. cilt, (Ankara: TTK Yayınları, 2009); Tufan Gündüz, XVII. ve XVIII. Yüzyıllarda Danişmendli Türkmenleri (İstanbul: Yeditepe Yayınları, 2005); Tufan Gündüz, Anadolu'da Türkmen Aşiretleri (İstanbul: Yeditepe Yayınları, 2015); Davut Şahbaz, XVI. Yüzyılda Ulu Yörük Teşekkülleri (Etrak-ı Büzürk) (Doktora Tezi, Ankara Üniversitesi Sosyal Bilimler Enstitüsü, 2018); İlhan Şahin, "1638 Bağdad Seferinde Zahire Nakline Memûr Edilen Yeni-il ve Halep Türkmenleri”, İstanbul Üniversitesi Edebiyat Fakültesi Tarih Dergisi 33 (1982), 227-234; Onur Usta, “Celâliliğin Türkmen Cephesi: 17.Yüzyıl Anadolu Kırsalında Türkmen Voyvodası ve Türkmenler” Kebikeç 33 (2012), 49-86; Ömer Düzbakar, "Hüdavendigar Sahasında Konar-Göçerler”, Uludağ Üniversitesi, Fen-Edebiyat Fakültesi Sosyal Bilimler Dergisi 4/1 (2003), 61-74.

13 Örnek olarak bkz. Cengiz Orhonlu, Osmanlı Imparatorluğunda Aşiretlerin İskanı (İstanbul: Eren Yayınları, 1987); Yusuf Halaçoğlu, XVIII. Yüzyılda Osmanlı İmparatorluğu'nun İskan Siyaseti ve Aşiretlerin Yerleştirilmesi (Ankara: TTK Yayınları, 2014).

14 Çalışmada, bahsedilen bu genel araştırmalarda dağınık halde yer alan muhtelif bilgilere yeri geldiğinde göndermeler yapılmıştır. Bu çerçevede, özellikle sefer bölgesinde yaşayan Bozulus, Danişmendlü, Halep ve Yeni-il Türkmenlerinden bahsedilirken Gündüz'ün ve Şahin'in çalışmalarına atıflar yapılmıştır.

15 İlgili çalışmalara örnek olarak bkz. Caroline Finkel, Administration of Warfare: The Ottoman Military Campaigns in Hungary, 1593-1606, (Wien: VWGÖ, 1988); Ömer İşbilir, XVII. Yüzyıl Başlarında Şark Seferlerinin İaşe, İkmal ve Lojistik Meseleleri (Doktora Tezi, İstanbul Üniversitesi Sosyal Bilimler Enstitüsü, 1996); Mehmet Yaşar Ertaş, Sultanın Ordusu (Mora Fethi Örneği 1714-1716) (İstanbul: Yeditepe Yayınları, 2007); Hakan Yıldız, 1711 Prut Seferi'nin Lojistik Faaliyetleri, (Doktora Tezi, Marmara Üniversitesi Türkiyat Araştırmaları Enstitüsü, 2000); Meryem Kaçan Erdoğan, II. Viyana Kuşatması (Doktora Tezi, Marmara Üniversitesi Türkiyat Araştırmaları Enstitüsü, 2001); M. Nuri Türkmen, Kamaniçe Seferinin Lojistik Hazırlıkları (Doktora Tezi, Ankara Üniversitesi Sosyal Bilimler Enstitüsü, 2002); Tahsin Ünal, IV. Murat ve Bağdat Seferi (Ankara: Berikan Yayınları, 2001); Mehmet İnbaşı, Ukrayna'da Osmanlılar Kaminiçe Seferi ve Organizasyonu (1672) (İstanbul: Yeditepe Yayınları, 2004); Süleyman Polat, IV. Murat'ın Revan Seferi Organizasyonu ve Stratejisi (Ankara: ATASE Yayınları, 2015).

16 Bu doğrultuda özellikle, IV. Murat'ın Bağdat ve Revan sefer organizasyonlarını temel alan Ünal'ın ve Polat'ın çalışmalarına yeri geldiğinde atıflar yapılmıştır. 


\section{IV. Murat Dönemi (1623-1640) Osmanlı Ordusunun Et İhtiyacının Karşılanmasında Konar-Göçerler}

Konar-göçer cemaatlerin Osmanlı seferlerinde üstlendikleri roller, Osmanlı iktisadi hayatında yerine getirdikleri faaliyetlerden farksız değildi. Nitekim bu grubun Osmanlı iktisadi hayatı içerisinde temel işlevi hayvancılık ve hayvancılığa bağl üretim faaliyetleriydi ${ }^{17}$. Bu kapsamda konar-göçer cemaatlerin en önemli rolü ürettikleri hayvanlarla yerleşik nizamda yaşayan tebaanın et ihtiyacını karşılamalarıydı. Öyle ki bu ihtiyacı sayıları milyonları bulan besledikleri koyunlarla sağlamışlard $1^{18}$. Bununla beraber konar-göçer gruplar besledikleri hayvanlarla sadece Osmanlı toplumunun değil, aynı zamanda Osmanlı ordusunun da et ihtiyacını temin etmişlerdi ${ }^{19}$. Özellikle savaş zamanlarında bu husus daha önem arz etmişti.

Herhangi bir savaş esnasında Osmanlı ordusunun et ihtiyacı karşılanırken iki temel yöntem kullanılmıştı. Bunlardan biri etin olağanüstü vergiler dâhilinde tedarik edilmesi diğeri ise iştira yöntemiyle temin edilmesiydi. Konar-göçer tebaadan da et, bahsedilen yöntemler kullanılarak talep ediliyordu. Bunun yanı sıra Osmanlı seferlerinde iaşe temin yöntemlerinde uygulanan temel prensip, ihtiyaç duyulan iaşe maddesi yahut mühimmatı en yakın bölgeden sağlamakt ${ }^{20}$. Bu genel prensibe et temininde de mümkün mertebe riayet edilmişti. Öyle ki çalışma kapsamında ele alınacak seferler olan doğu seferlerinde, bölgede yaşamını sürdüren Türkmen boylarına et temini hususunda sıkça başvurulmuştu. Bu kapsamda IV. Murat devri doğu seferlerinde et ihtiyacı büyük ölçüde Bozulus, Danişmendlü, Yeni-il ve Halep Türkmenleri olmak üzere bölgedeki konar-göçer tebaadan tedarik edilmişti.

\subsection{Hüsrev Paşa'nın Bağdat Seferi'nde (1630) Ordunun Et Teminine Konar-Göçerlerin}

\section{Katkısı}

IV. Murat döneminde Safeviler tarafından ele geçirilen Bağdat'ın yeniden fethedilmesi için düzenlenen seferlerden birisi Hüsrev Paşa'nın seraskerlik yaptığı Bağdat seferiydi. Hüsrev Paşa'nın Haziran 1629'da serasker sıfatıyla Üsküdar'a geçmesiyle başlayan sefer yaklaşık 1,5 yıl devam etmiş, fakat neticesiz bir deneme olarak kalmışt ${ }^{21}$. Bununla beraber uzun süreli bir organizasyon olan Hüsrev Paşa'nın Bağdat Seferi sürecinde önemli hazırlıklar da yapılmıştı. Nitekim bu hazırlık ve sefer sürecinde konar-göçer cemaatlere de önemli roller düşmüştü. Konar-göçerler savaş esnasındaysa et ihtiyacını karşılama işini üzerine düşen yükümlülükler vasıtasıyla yerine getirmişlerdi. Hiç şüphesiz bunların başında sürsat yükümlülügüuyle temin edilen koyun gelmekteydi. Sürsat arpa, un, ekmek, sadeyağ, bal, koyun, odun gibi ağırlıklı olarak

17 Orhonlu, Osmanlı İmparatorluğunda Aşiretlerin İskânı, 20.

18 Tufan Gündüz, Bozkırın Efendileri-Türkmenler Üzerine Makaleler (İstanbul: Yeditepe Yayınlar1, 2015$), 123$.

19 Usta, “Celâliliğin Türkmen Cephesi: 17.Yüzyıl Anadolu Kırsalında Türkmen Voyvodası ve Türkmenler”, 51.

20 Polat, IV. Murat'in Revan Seferi Organizasyonu, 409-410.

21 Sefer süreciyle ilgili bkz. Kerim Yans, IV. Murad Devrinde Osmanll-Safevî Münasebetleri (Doktora Tezi, İstanbul Üniversitesi Edebiyat Fakültesi Osmanlı Müesseseleri ve Medeniyeti Tarihi Kürsüsü, 1977), 103-112; Özer Küpeli, Osmanll-Safevi Münasebetleri (İstanbul: Yeditepe Yayınları, 2014), 174-193; Halil İnalcık, "Hüsrev Paşa", TDV İslam Ansiklopedisi, c. 19, (İstanbul: TDV Yayınları, 1999), 38-39. 
iaşe maddelerinden oluşan ve seferler esnasında Osmanlı tebaasının genelinden aynî alınan bir yükümlülüktü22 ${ }^{2}$. Bununla birlikte konar-göçer gruplar bu maddeler içerisinden ağırlıklı olarak koyun ürettiklerinden, sürsat mukabilinde tarh ve tahsil edilen koyun üzerinden gerçekleşmişti. Nitekim Hüsrev Paşa'nın Bağdat Seferi’nde ordunun iaşe ihtiyaçlarının karşılanması adına sürsat kapsamında konar-göçer cemaatlerden kayda değer miktarlarda koyun talep edilmişti.

Tablo 1: Hüsrev Paşa'nın Bağdat Seferi'nde (1630) Konar-Göçer Cemaatlerden Sürsat Mukabilinde Talep Edilen Koyun ${ }^{23}$

\begin{tabular}{llll}
\hline Cemaat Adı & Talep Edilen Koyun & Cemaat Adı & Talep Edilen Koyun \\
\hline Bozulus & 5.000 & Türkmen-i Yeni-il & 5.000 \\
Türkmen-i Halep & 5.000 & Karaulus & 5.000 \\
Danişmendlü & 2.000 & Şikaki & 5.000 \\
Lekvanik & 2.000 & Türkmen-i Yeni-il & 10.000 \\
Bozulus (An canib-i Anadolu) & 5.000 & Perakende-i Bozdoğan & 5.000 \\
Toplam & $\mathbf{4 9 . 0 0 0}$ & & \\
\hline
\end{tabular}

Tablo 1'den anlaşılacağı üzere Hüsrev Paşa'nın Bağdat Seferi esnasında sefer bölgesinde yer alan sekiz farklı konar-göçer cemaatten sürsat mukabilinde 49.000 adet koyun talep edilmişti. Bu süreçle ilgili incelenen kaynakta, konar-göçer cemaatlerden Hüsrev Paşa'nın Bağdat Seferi için istenen sürsat koyunlarının tarh ve tahsil süreciyle ilgili malumat da mevcuttur. Buna göre 1628-9 (H.1038) yılında talep edilen bu koyunların teslimi yaklaşık bir yıl sonra 1629-30 (H.1039) yılında, esnasında gerçekleşmişti. Bu süreçte sürsat mükellefiyeti çerçevesinde istenilen koyunlar, belirtilen yerlerde ordu koyun eminine temessük karşılığ teslim edilmişti. Mesela Karaulus Cemaati'nden talep edilen 5.000 adet koyun 2 Ocak 1630 (17 Cemâziyelevvel 1039) tarihinde Musul menzilinde ordu koyun eminine teslim edilmişti. Ne var ki büyük çoğunluğu Türkmenlerden oluşan konar-göçer cemaatlerin teslim etmekle yükümlü oldukları koyunların bir kısmını veremedikleri de vakiydi. Öyle ki Türkmen-i Yeni-il Cemaati'nin vermekle yükümlü olduğu 5.000 koyundan ancak 2.180 adedi 30 Ağustos 1629 (10 Muharrem 1039) tarihinde teslim edilmiş, 2.820 adediyse bakiye kalmıştı. Danişmendlü Türkmenleri ise mükellefiyetlerinin büyük kısmını tamamlamış, yani 2.000 koyunun 1.971 adedi 3 Eylül 1629 (14 Muharrem 1039) tarihinde koyun eminine teslim edilmişti. Anadolu canibindeki Bozulus Türkmenleri ise vermeleri gereken 5.000 koyunun 2.946 adedinin teslimini sağlamışlardı. Bakiye kalan 2.056 koyun için ise her bir koyun karşılığı 2 kuruş üzerinden bedel ödemeleri istenmişti ${ }^{24}$.

22 Lütfi Güçer, XVI-XVII Asırlarda Osmanlı Imparatorluğu'nda Hububat Meselesi ve Hububattan Alınan Vergiler (İstanbul: İstanbul Üniversitesi Yayınları, 1964), 93.

23 Cumhurbaşkanlığı Devlet Arşivleri Başkanlığı Osmanlı Arşivi (BOA), Bâb-1 Defteri, Mevkufat Kalemi Defterleri (D.MKF), 27441.

24 BOA, D.MKF. 27441, 61. İlgili süreçte Bozulus Türkmenlerinden sürsat çerçevesinde gönderemedikleri koyunların yerine, 2 kuruş bedel belirlenerek nakdî ücretinin istendiği bir başka belge örneği için bkz. Cumhurbaşkanlığı Devlet Arşivleri Başkanlığı Osmanlı Arşivi (BOA), Maliyeden Müdevver Defterleri (MAD) 3475, 31. 
Hüsrev Paşa'nın Bağdat Seferi için konar-göçer cemaatlerden 1628-9 (H.1038) tarihinden sonraki yıllarda da sürsat kapsamında koyun talep edilmişti. Ancak savaş esnasında bir kısım koyun talebi tamamen karşılıksız kalmıştı. 8 Temmuz 1631 (8 Zilhicce 1040) tarihinde Bozulus ve Danişmendlü Türkmenleri görevlilerine gönderilen bir hüküm bu durumu kanıtlar nitelikteydi. Buna göre 1629-30 (H.1039) ve 1630-31 (H.1040) senelerinde sürsat mukabilinde Bozulus Türkmenlerine her sene için 5.000 olmak üzere toplamda 10.000 koyun, Danişmendlü Türkmenlerine ise senelik 2.000 olmak üzere toplamda 4.000 adet koyun tarh edilmişti. Lakin ilgili cemaatler koyun talebini aynî olarak karşılayamamıştı. Bunun üzerine her bir koyuna 2 kuruş bedel biçilerek ilgili miktarların cemaat voyvodaları tarafından toplanıp ordu hazinesine ulaştırılması emredilmişti ${ }^{25}$. Anlaşılan ardı sıra gelen mükellefiyetler bazı konar-göçer cemaatlerin o zamanki sahip oldukları koyun kapasitelerinin üzerindeydi. Bu yüzden yükümlülüklerini aynî olarak ifa edememiş, nakdî ödemek zorunda kalmışlardı.

Hüsrev Paşa'nın Bağdat Seferi’nde olağanüstü vergiler dışında, koyun ihtiyacını karşılamak için kullanılan bir diğer yöntem "mükellefiyet şeklinde yürütülen” iştiraydı. Bu satın alma yönteminin mükellefiyet şekline dönüşmesinde iki önemli unsur vard1. Bunlardan ilki, savaş esnasında önem arz eden gıda ve teçhizatın, piyasa koşullarına göre daha uygun fiyatta, belirlenen bir bedel üzerinden, belirlenen kişi, grup ya da bölgeden alınması, ikincisiyse bu koşullarda istenilen gıda yahut mühimmatı temin edemeyen muhataplardan nakdî bir ücret talep edilmesiydi ${ }^{26}$. Hüsrev Paşa'nın Bağdat Seferi sürecinde et temini hususunda iştira ile ilgili toplu bir belgeye rastlanılmamakla beraber, bu ihtiyacın karşılanması için konar-göçer cemaatlerin yöneticilerine gönderilmiş muhtelif hükümler, iştira yöntemi kullanılarak da koyun talep edildiğini göstermekteydi. Nitekim 25 Haziran 1631 (25 Zilkade 1040) tarihinde Maraş Beylerbeyi Hüseyin’e gönderilen hükümde iştira yöntemiyle 2.040 koyunun satın alınıp orduya gönderilmesi istenmişti. Buna göre ilgili miktarın en büyük parçası 1.200 koyun ile bölgedeki Döğerli aşiretinden satın alınması istenmiş, geriye kalan 840 adet koyunsa Göbekli, Behram, Hasan gibi daha küçük teşekküldeki aşiretlerden temin edilmesi emredilmişti ${ }^{27}$. Anlaşılacağı üzere bu iştiraların mükellefiyet şeklinde yürütüldüğünün kanıtı, koyunların hangi cemaatlerden hangi sayıda satın alınması isteğinin belirtilmiş olmasıydı. Koyun iştirası çerçevesinde kayda geçmiş bir diğer belgeyse, 8 Temmuz 1631 (8 Zilhicce 1040) tarihinde Badıllı Türkmen Cemaati'nin konup göçtükleri bölgelerdeki kadılara, cemaatin kethüdasına ve ihtiyarlarına gönderilmişti. İlgili belgede Badıllı Cemaati'nden 1.000 adet koyun ordunun et ihtiyacını karşılamak adına talep edilmişti. Söz konusu belgede iştirası istenen her bir koyun için ödenecek rakam belirtilmemişti. Ancak koyunların üçer yaşında, besili ve sefer için

25 BOA, MAD. 8475, 28.

26 Ayrıntı için bkz. Süleyman Polat, "Osmanlı Sefer Organizasyonunda Pratik Çözümler: 1634-1635 (H. 1044$)$ Tarihlerinde Karahisar-1 Şarki’de "Mükellefiyet Şeklinde Yürütülen İştira” ile Zahire Temini”, Gazi Akademik Bakış IV/8 (2011), 161-174.

27 BOA, MAD. 8475, 20. 
uygun koyunlar olması gerektiği ve satın alım bedellerinin ordu hazinesinden karşılanacağı bahsedilmişti ${ }^{28}$.

Hüsrev Paşa'nın Bağdat Seferi esnasında konar-göçer cemaatlerin koyun iştirası sürecinde yükümlülüklerini yerine getirmekte zorlandı̆̆ı durumlar da mevcuttur. Öyle ki Hısn-1 Mansur Kadısı'na ve bölgede koyun iştirası için görevlendirilen sipahi zümresinden Bekir'e gönderilen hüküm bu duruma örnek teşkil etmektedir. 8 Temmuz 1631 (8 Zilhicce 1040) tarihli hükme göre, bölgede bulunan Rişvan Aşireti 3.500 adet koyun tedarikiyle mükellef kılınmıştı. Ancak talep edilen koyunların aşiret tarafından temin edilememesi üzerine, aşiret mensuplarınca bu miktarın bir kısmının affedilmesi, geriye kalan kısmınınsa keçi olarak temin edilip ödenmesi istenmişti. Bunun üzerine Rişvan Aşireti'nin iştira çerçevesindeki talepleri kısmen kabul edilmişti. Buna göre iştira kapsamında teslim etmeleri gereken hayvan miktarında bir değişikliğe gidilmemiş, ancak ordunun et ihtiyacı için satmaları gereken 3.500 adet koyunun yarısını keçi olarak temin etmeleri kabul edilmişti ${ }^{29}$. Anlaşıldığ üzere iştira sürecinde de konar-göçer cemaatlerin kapasitelerinin üstünde koyun talebi gelmişti. Öyle ki buradan sefer gibi olağanüstü bir durumda devletin böyle bir talepte bulunurken, konar-göçerlerin o anki mevcut koyun ya da keçi sayısını kesin olarak bilmediği anlaşılmaktadır. Bu gibi durumlarla karşılaşan konar-göçer cemaatler ise vaziyetlerini yetkili mercilere izah edip, yükümlülüklerini ellerinde bulunan yahut daha çok bulunan hayvan ile yerine getirmek istemişse de seferi organize eden yöneticiler, hem mükellefiyetin mümkün olduğunca eksiksiz yerine getirilebilmesi, hem de askerlerin alışık oldukları et cinsinin sağlanması çerçevesinde bir karar vermişlerdi.

\subsection{Revan Seferi Esnasında Konar-Göçerlerin Et Hususundaki Katkıları}

Revan Seferi esnasında ${ }^{30}$ ordunun et ihtiyacının karşılanması çerçevesinde ön plana çıkan konar-göçer cemaatlerin başında Bozulus Türkmenleri yer almıştı. Bozulus Türkmenlerinden gerek mükellefiyet çerçevesinde gerekse satın alma yoluyla koyun temin edilmişti. Sefer planı dâhilinde Osmanlı ordusunun tüm askerî gücünün bir araya geldiği yer Erzurum'du ${ }^{31}$. Sefer için son hazırlıkların yapılacağı ve dolayısıyla uzun bir konaklamanın gerçekleşeceği menzil olan Erzurum'da askerin iaşesinin, özellikle et ihtiyacının karşılanması önemli bir sorundu. Bu doğrultuda henüz Osmanlı ordususun Üsküdar'dan Revan'a doğru hareketinin yeni başladığı bir zamanda 1635 yılının Mart/Nisan ayında (H.1044 yılının Şevval) Bozulus Kadısı'na ve Bozulus Voyvodası Mehmet'e bir emir gönderilmişti. Buna göre Bozulus Voyvodası'ndan 15.000 koyunun Bozulus Türkmenlerinden satın alınıp, Osmanlı ordusu Erzurum'a ulaşmadan

28 BOA, MAD. 8475, 24. İştira için bir başka hüküm Ruha Kadısı'na gönderilmişti. Bölgedeki aşiretlerden 700 koyun satın alınıp orduya gönderilmesi istenmişti. Bu hükümde iştira süreciyle ilgili ifade edilen en önemli fark, istenilen koyunların her biri için 1 kuruş bedelin belirlenmiş olmasıydı. BOA, MAD. 8475, 53.

29 BOA, MAD. 8475, 29.

30 Revan Seferi'nin organizasyonu ve seferin gelişimi için bkz. Polat, IV. Murat'ın Revan Seferi Organizasyonu; Yans, "IV. Murad Devrinde Osmanl-Safevî Münasebetleri”, 123-148; Küpeli, Osmanll-Safevi Münasebetleri, 207-221.

31 Polat, IV. Murat'in Revan Seferi Organizasyonu, 167-168. 
gönderilmesi istenmişti. Emrin gönderilmesinin akabinde Bozulus Voyvodası Mehmet'e verilen takribi süre iki aydı. Nitekim yaklaşık bir ay önceden koyunların satın alınıp Erzurum'a ulaştırılması istenmişti. Ayrıca ordunun Erzurum'a ulaşması için geçecek bir aylık sürede ise işin erbabı çobanlar ile koyunların otlu ve sulu yerlerde beslenmesi ve sonrasında ordu koyun eminine teslim edilmesi yine voyvodadan istenenler arasındayd $1^{32}$. Koyunların satın alınması sırasında her bir koyun için belirlenen bedel 1,5 kuruştu. Nitekim bu bedel Hüdavendigar livasının bedel-i nüzul malından ve Bozulus mukataası malından sağlanmışt1 ${ }^{33}$.

Yukarıda bahsedildiği üzere Osmanlı ordusunun et ihtiyacının önemli bir kısmı satın alınanlar dışında, sürsat olarak bilinen mükellefiyet ile temin edilmekteydi. Revan Seferi'nde sürsat mukabilinde Anadolu, Karaman, Adana, Rum, Maraş, Erzurum, Trabzon Eyaletlerine ait toplam 511 kazadan 29.815 adet koyun tahsil edilmişti ${ }^{34}$. Buna ilave olarak, bir önceki seferde vuku bulduğu gibi, sürsat vasıtasıyla temin edilen koyunun önemli miktarı, koyun yetiştiren cemaatlerden sağlanmıştı.

Tablo 2: 1635 Revan Seferi’nde H.1043-44 (1634-35) Cemaatlerden Sürsat Mukabilinde Talep Edilen Koyun $^{35}$

\begin{tabular}{llll}
\hline Cemaat Adı & Talep Edilen Koyun & Cemaat Adı & Talep Edilen Koyun \\
\hline Bozulus & 5.000 & Türkmen-i Yeni-il & 5.000 \\
Türkmen-i Halep & 5.000 & Karaulus & 5.000 \\
Danişmendlü & 1.600 & Şikaki & 5.000 \\
Lekvanik & 400 & & \\
Toplam & $\mathbf{2 7 . 0 0 0}$ & & \\
\hline
\end{tabular}

Tablo 2'den de anlaşılacağı üzere Revan Seferi'nde, Bozulus Türkmen Cemaati'nden 5.000 adet koyunun sürsat çerçevesinde tarhı ve tahsili sağlanmışt1 ${ }^{36}$. Bozulus Türkmen Cemaati’ne tarhı ve tahsili gerçekleşen sürsatın yanında, aynı yöntem kabilinde bölgedeki diğer koyun yetiştiriciliği yapan cemaatlere de hatırı sayılır miktarlarda koyun istenmişti. Bu doğrultuda Türkmen-i Yeni-il Cemaati'nden 5.000, Türkmen-i Halep Cemaati’nden 5.000, Karaulus Cemaati'nden 5.000, Şikaki Cemaati'nden 5.000, Danişmendlü Cemaati'nden 1.600 ve Lekvanik Cemaati'nden 400 adet sürsat bedeli karşılığında koyun tarh edilmişti ${ }^{37}$. Bununla birlikte tarh edilen bedelin tahsili esnasında da birtakım sıkıntılar yaşanmıştı. Nitekim Yeni-il ve Türkmen-i Halep cemaatlerinin Hüsrev Paşa zamanından bu yana vergi yükümlülüklerini ödemedikleri dile getirilip, Revan Seferi mukabilinde bakiye kalan 1.000 adet sürsat koyununu acilen ödemeleri talep edilmişti ${ }^{38}$.

32 BOA, MAD. 7275, 4.

33 BOA, MAD. 7275, 2, 4. Usta, “Celâliliğin Türkmen Cephesi: 17.Yüzyıl Anadolu Kırsalında Türkmen Voyvodası ve Türkmenler", 52.

34 Polat, IV. Murat'in Revan Seferi Organizasyonu, 259.

35 Cumhurbaşkanlığı Devlet Arşivleri Başkanlığg Osmanlı Arşivi (BOA), Kamil Kepeci Defterleri (KK), 2575.

36 BOA, MAD. 4433, 70 .

37 BOA, KK. 2575, 58.

38 Polat, IV. Murat'in Revan Seferi Organizasyonu,259; BOA, MAD. 7392, 3-4. 


\subsection{Bağdat Seferi’nde Ordunun Et Teminine Konar-Göçer Cemaatlerin Katkısı}

Revan Seferi sonrasında sadrazam henüz İstanbul'a avdet etmemişken Bağdat Seferi'nin hazırlıklarına hızlı bir şekilde başlamışt ${ }^{39}$. Bu hazırlıkların en önemli parçalarından birini de et temini için koyun talebi oluşturmuştu. Nitekim Revan Seferi'nin hazırlıkları sırasında vuku bulduğu gibi Bağdat Seferi’nin hazırlık sürecinde de et temini için gönderilen hükümler konar-göçer cemaatlerin yaşamını sürdürdüğü bölgelerdeki görevlilere yapılmıştı. Bu çerçevede sefer bölgesinde bulunan Türkmen ve konar-göçer cemaatlerden koyun talebi doğrultusunda gönderilen genel hükümlerde 45.200 adet koyun talep edilmişti.

Tablo 3: 1638 Bağdat Seferi’nde Konar-Göçer Cemaatlerden İştira ile Talep Edilen Koyun Miktari $^{40}$

\begin{tabular}{llll}
\hline $\begin{array}{l}\text { Cemaat Adı ya da Koyun } \\
\text { Talep Edildiği Yer }\end{array}$ & Talep Edilen Koyun & $\begin{array}{l}\text { Cemaat Adı ya da Koyun } \\
\text { Talep Edildiği Yer }\end{array}$ & Talep Edilen Koyun \\
\hline Bozulus & 2.000 & $\begin{array}{l}\text { Türkmen-i Yeni-il ve } \\
\text { Türkmen-i Halep }\end{array}$ & 5.000 \\
Ağraz & 3.000 & Karaulus & 12.000 \\
Danişmendlü & 2.000 & Nusaybin & 2.000 \\
Lekvanik & 1.000 & Mardin & 3.000 \\
Rişvan & 5.000 & Tokat & 2.200 \\
İfraz-1 Zulkadriyye & 3.000 & Şikaki & 5.000 \\
Toplam & $\mathbf{4 5 . 2 0 0}$ & & \\
\hline
\end{tabular}

1636-7 (H. 1046) yılının sonunda, konar-göçer cemaatlerin yaşadığı bölgelerdeki en yüksek rütbeli mülki ve mali amirlere gönderilen hükümlerde, koyun tedarikinin ayrıntıları da belirtilmişti. Buna göre savaşa bizzat katılan padişahın "Matbaah-1 Âmire"si ve "kapıkullarının meydanları" için gerekli koyunların temini iştira yöntemiyle sağlanacaktı. Koyunların her biri üç ya da dört yaşında "etli, semiz, alâ" ve erkek olacaktı. İştira için gerekli meblağ ilgili konar-göçer cemaatinin 1637-8 (H. 1047) tarihli mukataa gelirinden temin edilecekti. Her bir koyun için satın alma bedeli olarak 1,5 kuruş belirlenmişti. Bu süreçte iştirayı yürütecek olan mülki ve mali amirlerden istenilen bir diğer önemli husus, mal sahiplerine farklı gerekçelerle eksik ödeme yapılmaması ve satın alınacak koyunların belirtilen özelliklere sahip olmasıydı. Özellikle mülki amirlerin iştiradan sonra da işleri bitmiyordu. Nitekim ilgili görevlilerden satın alınacak koyunların sağlıklı ve besili tutmaları, koyun sürme ve bakma işinden anlayan çobanlar vasıtasıyla ordu koyun eminine temessük karşılı̆̆ Seferi'nde askerin iaşesi için cemaatlerden talep edilen koyunların iştira sürecinde birtakım

39 Bağdat seferinin hazırlık süreci ve sefer organizasyonu için bkz. Tahsin Ünal, "Savaşa Çıkan Osmanlı Ordusunda Lojistik İşleri -IV. Murad'ın Bağdat Seferi Hazırlıklar1-” Türk Kültürü, V/58, (1967), 728-740; Ünal, IV. Murat ve Băgdat Seferi; Yans, “IV. Murad Devrinde Osmanl-Safevî Münasebetleri”, 164-196; Küpeli, Osmanll-Safevi Münasebetleri, 235-268.

40 BOA, MAD. 3443.

41 BOA, MAD. 3443, 44, 129, 130. 
sıkıntılar da yaşanmıştı. Nitekim 31 Ocak 1639 (26 Ramazan 1048) tarihli kayda göre, geçen sene "Karaulus taifesinden" iştirası ferman olunan 12.000 koyundan 3.000 adedinin teslimi yapılmamıştı. Bunun üzerine daha önceden bu iş için görevlendirilen Diyarbakır Beylerbeyi ve Defterdarı'ndan eksik koyunların gönderilmesi istenmişti. Ayrıca görevlilerden eksik koyunların, geçen sene belirlenen şartlara göre temin edilmesi belirtilmişti. Bu kapsamda 3.000 koyunun iştirası için yine 1,5 kuruş bedel ile adı geçen cemaatten satın alınması istenmişti. Lakin koyun için belirlenen bedel geçen sene iştira için görevlendirilmiş kişilere verildiyse yeni ödeme yapılmaması, verilmediyse ilgili cemaatin gelecek seneki mukataa gelirinden ödenmesi emredilmişti ${ }^{42}$.

Yukarıda verilen örnekler dışında Bağdat Seferi'nin hazırlık ve kuşatma sürecinde, konargöçer cemaatlerden iştira mukabilinde koyun talebi devam etmişti. Mesela 5 Ağustos 1637 (13 Rebî‘ülevvel 1047) tarihinde Bozulus ve Danişmendlü Türkmen Voyvodası'na gönderilen hükümde, Süleyman Bey adında bir görevlinin ilgili Türkmen cemaatlerinden satın aldığ 1870 adet koyunu orduya sevk etmesi istenmiştił ${ }^{43}$ Y Yine 27 Ağustos 1637 (5 Rebî‘ülâhır 1047) tarihli bir başka hükümde, Diyarbakır ve çevresinde bulunan aşiretlerden 5.000 adet koyun satın alınması emredilmişti ${ }^{44}$. Ayrıntılı bir şekilde koyun iştirasının yapılmasını emreden bir başka hüküm, 3 Aralık 1637(15 Recep 1047) tarihinde Yeni-il ve Türkmen-i Halep Voyvodası'na gönderilmişti. Diğer hükümlere benzer bir biçimde satın alınacak koyunların 3-4 yaşlarında "sefere ve bıçağa yarar" ve erkek olmaları vurgulanmasının ardından, Yeni-il ve Türkmen-i Halep konar-göçer reayasından 5.000 adet koyunun satın alınması görevlilerden talep edilmişti. Satın alınacak koyunların iştirası için belirlenen miktar yine her bir koyun için 1,5 kuruştu ve iştira için gerekli kaynak, bahsi geçen Türkmen Cemaati'nin mukataa gelirlerinden temin edilecekti. Koyunların satın alınması tamamlandıktan sonra ordu koyun eminine temessük karşılığı teslim edilecekti. Koyun emini bu iştira sürecinin son aşamasında yer alacak, koyunların istenilen sayıda ve istenilen şartlarda olup olmadığının kontrolünü yapacak ve şartlar sağlandığı takdirde koyunları teslim alınacaktı ${ }^{45}$. Seferin devam ettiği 1638 yılının Mayıs/Haziran (1048 Muharrem) ayına gelindiğinde, Türkmen cemaatlerine koyun iştirası için başka hükümler de gönderilmişti. Nitekim Bozulus Voyvodası'na, Danişmendlü Voyvodası Kenan'a ve Lekvanik Voyvodası'na gönderilen hükümlerde, ismi geçen cemaatlerin 1638-9 (H. 1048) mukataa geliri kullanılarak koyun iştirası yapılması emredilmişti ${ }^{46}$.

Bununla beraber Bağdat Seferi esnasında konar-göçer cemaatlerden yapılması planlanan bu iştiraların hangi oranlarda tamamlandığı da takip edilebilmişti. Nitekim seferin koyun

42 BOA, MAD. 2841, 165. Benzer bir biçimde 10 Ekim 1637 (20 Cemâziyelevvel 1047) tarihinde Rişvan Zabiti'ne gönderilen hükümde 1636-7 (H. 1046) yılı mukataa gelirleri kullanılarak talep edilen 5.000 koyunun 4.000 adedinin orduya gönderildiği ifade edilmiş, kalan 1.000 adedinin ise kısa sürede orduya teslimi istenmişti. BOA, MAD. 3443, 104.

43 BOA, MAD. 3443, 52.

44 BOA, MAD. 3443, 73.

45 Topkapı Sarayı Müzesi Arşivi (TSMA), E. 5222-28.

46 BOA, MAD. 3443, 243, 249, 250. 
ihtiyacı çerçevesinde koyun emini ve koyun teminini organize eden görevliler tarafından tutulan kayıtlarda, planlamalar kapsamında talep edilen koyunların büyük ölçüde temin edildiği anlaşılmaktadır. Bu çerçevede konar-göçer cemaatlerden talep edildiğini belirttiğimiz 45.200 adet koyundan daha fazlası, 45.775 adedi satın alınmıştı.

Tablo 4: 1638 Bağdat Seferi’nde Konar-Göçer Cemaatlerden İştira ile Temin Edilen Koyun Miktari $^{47}$

\begin{tabular}{llll}
\hline $\begin{array}{l}\text { Cemaat Adı ya da Koyun } \\
\text { Talep Edildiği Yer }\end{array}$ & Talep Edilen Koyun & $\begin{array}{l}\text { Cemaat Adı ya da Koyun } \\
\text { Talep Edildiği Yer }\end{array}$ & Talep Edilen Koyun \\
\hline Bozulus & 2.000 & $\begin{array}{l}\text { Türkmen-i Yeni-il ve } \\
\text { Türkmen-i Halep }\end{array}$ & 5.000 \\
Ağraz & 3.000 & Karaulus & $9.000+1.000$ \\
Danişmendlü & 2.000 & Nusaybin & 735 \\
Lekvanik & $?$ & Mardin & 1.250 \\
Rişvan & 5.000 & Şikaki & 12.000 \\
İfraz-1 Zulkadriye & 3.000 & Tokat & 1.790 \\
Toplam & $\mathbf{4 5 . 7 7 5}$ & & \\
\hline
\end{tabular}

Yukarıdaki tabloyu (Tablo 4), seferin hazırlıkları esnasında konar-göçer cemaatlerden talep edilen koyunlarla ilgili oluşturulan ilk tabloyla (Tablo 3) kıyasladığımızda, Bozulus, Türkmen-i Yeni-il ve Türkmen-i Halep, Danişmendlü, Ağraz, İfraz-1 Zulkadriyye ve Rişvan cemaatlerinden iştira kapsamında talep edilen koyunların tamamının alındığı görülmektedir. Anlaşılan bu cemaatlerden iştira talebi sonrasında eksik kalan koyunlar da tedarik edilmişti. Bunun yanında Karaulus Cemaati'nden talep edilen 12.000 koyunun ilk etapta 9.000 adedinin iştirası sağlanmış, sonraki süreçte eksik kalan koyunların 1.000 adedi daha satın alınarak orduya ulaştırılmış, lakin talep edilen miktardan 2.000 koyun eksik kalmıştı. Ayrıca Nusaybin ve Mardin'den iştirası talep edilen koyunlardan 3.015 adedi, Tokat tarafından iştirası beklenen koyunlarda 410 adedi satın alınamamıştı. Ne var ki eksik kalan bu miktarlar fazlasıyla Şikaki Cemaati'nden sağlanmıştı. Öyle ki ilk talepte iştira için 5.000 adet istenen koyun, sefer sürecinde 12.000 adede çıkmışt ${ }^{48}$. Bağdat Seferi sürecinde iştira öncesi ve sonrasındaki genel ve özel kıyaslamalardan çıkan sonuç, konar-göçer cemaatlerden talep edilen koyunların büyük ölçüde sağlanmış olduğuydu. Bu durum et ihtiyacını organize eden görevlilerim başarısı olarak yorumlanabileceği gibi, padişahın da katıldığı bu sefer organizasyonunda, gerek tebaa olsun gerekse yönetici, herkesin yükümlülüklerini muntazaman yerine getirdiği şeklinde de düşünülebilir.

1638 Bağdat Seferi sürecinde konar-göçer cemaatlerden iştira ile temin edilen koyun yanında, sürsat kapsamında da koyun talep edilmişti. Ne var ki araştırmamızda 1638 Bağdat Seferi'nde sürsat mukabilinde konar-göçer cemaatlerden talep edilen koyun sayısını toplu bir biçimde

47 BOA, MAD. 18186.

48 BOA, MAD. 18186, 4. 
gösteren bir vesikaya rastlanamamıştır. Ancak sürece ilişkin arşiv kaynaklı yapılan takibatta, Bağdat Seferi esnasında da konar-göçer cemaatlerden önemli miktarlarda koyunun sürsat yükümlülüğü çerçevesinde temin edildiği anlaşılmaktadır. Öyle ki Yeni-il ve Türkmen-i Halep Voyvodası'na gönderilen 1636-7 (H. 1046) tarihli bir hükümde, sefer için üzerlerine düşen sürsat koyunlarını göndermeleri istenmişti ${ }^{49}$. Yeni-il ve Türkmen-i Halep Voyvodası'na gönderilen 6 Kasım 1637 (17 Cemâziyelâhir 1047) tarihli bir başka hükümdeyse sürsat kapsamında istenen koyunlar hakkında daha ayrıntılı bilgiler mevcuttu. Buna göre, adı geçen cemaatlerin sürsat yükümlülüğü çerçevesinde, önceki yıllardan bakiye kalan miktarla beraber toplam, 18.000 koyun vermeleri gerektiği belirtilmiş, lakin bu miktarın sadece 6.000 adedinin tahsili gerçekleşmişti. Nitekim hükümde, önceki yıllardan bakiye kalan 12.000 sürsat koyununun bir an evvel tahsil edilip, ordu koyun eminine teslim edilmesi istenmişti ${ }^{50}$. Bununla birlikte sürsat kapsamında koyun istenilen cemaatler sadece Yeni-il ve Halep Türkmenleriyle sınırlı değildi. Öyle ki bu kapsamda Lekvanik Cemaati'nden 400 sürsat koyunu talep edilmiş, Danişmendlü Türkmenlerinden ise üzerlerine düşen 300 sürsat koyununu orduya ulaştırmaları emredilmişti ${ }^{51}$.

1638 Bağdat Seferi’nin hazırlık aşamasında parça parça sürsat koyunu talebini gösteren örnekler dışında, et organizasyonunu yürüten görevliler tarafından tutulan kayıtlarda, sürsat kapmasında konar-göçer cemaatlerden hangi oranda et temin edildiği de tespit edilebilmektedir. Buna göre Bağdat Seferi'nde 42.748 adet koyun sürsat çerçevesinde temin edilmişti. Bu miktarın 25.433 adedi Anadolu, Karaman, Rum, Diyarbakır gibi sefer güzergâhında olan eyaletlere bağlı 230 kazadan toplanmıştı. Kazalarda sakin reayadan alınan bu miktarın dışında, çarpıcı oranda koyun konar-göçer reayadan temin edilmişti. Nitekim Bozulus Türkmenlerinden 6.000, Yeni-il ve Halep Türkmenlerinden 7.615, Danişmendlü Türkmenlerinden 2.300, Lekvanik'den 900 ve Bozdoğan Türkmenlerinden 500 koyun olmak üzere toplamda 17.315 koyun sürsat kapsamında tahsil edilmişti ${ }^{52}$. Anlaşılan sürsat mukabilinde sağlanan koyunun yaklaşık \%41'i bölgedeki konar-göçer cemaatten toplanmıştı. Seferin sonunda tutulan ve sürsat verilerini gösteren bu kayıtlara göre, Yeni-il ve Türkmen-i Halep cemaatleri eskiye yönelik sürsat taleplerinin küçük bir kısmını karşılayabilmişlerdi. Anlaşılan Yeni-il ve Türkmen-i Halep cemaatleri sahip oldukları koyun kapasiteleri çerçevesinde o yılki vergi yükümlülüklerini yerine getirmişler, ancak eskiden kalan aynî vergi yükümlülüklerinin küçük bir kısmını ödemişlerdi.

1638 Bağdat Seferi esnasında konar-göçer cemaatlerden sürsat ve iştira gibi yükümlülüklerle koyun talebinin dişında, olağan olarak nakdî ödedikleri vergilerin aynî talep edilmesiyle de koyun tedarik edilmişti. Bu çerçevede Sivas Eyaleti'nde bulunan kadılara, Aksaray, Ankara, Kırşehir ve Çankırı sancakbeylerine hükümler gönderilmişti. Buna göre, adı geçen yerlerde kışlayan konar-göçer reayanın ödemeleri gereken resm-i kışlak vergisi yerine, ordunun et ihtiyacını karşılamak üzere her haneden bir koyun alınarak ordu koyun eminine ulaştırmaları

49 BOA, MAD. 3443, 130.

50 BOA, MAD. 3443, 131.

51 BOA, MAD. 3443, 130, 250; BOA, MAD. 2841, 85.

52 BOA, MAD. 18186, 5-8. 
istenmişti ${ }^{53}$. Anlaşılan devlet acil ihtiyaçları mukabilinde, nakdî gelirlerinden vazgeçmiş, olağanüstü bir durumda esnek bir çözüm geliştirmişti.

\section{IV. Murat Dönemi (1623-1640) Seferlerde Konar-Göçerlerin Taşımacılık Kapsamındaki Katkıları}

Konar-göçer cemaatlerin ürettikleri koyunlar ve devletin et ihtiyacına sağladığı katkılar yanında, taşımacılık işinde de önemli roller üstlenmişlerdi. Gerek ürettikleri develeri satarak gerekse sahip oldukları develer ile bizzat yaptıkları taşımacılıkla, bu alanda önemli vazifeler yerine getirmişlerdi. Nitekim konar-göçer cemaatler savaş zamanlarında da aynı işleri yürüterek, savaşın başarısı için kritik görevleri yerine getirmişlerdi ${ }^{54}$.

\subsection{Hüsrev Paşa'nın Bağdat Seferi'nde (1630) Konar-Göçerlerden Talep Edilen Deve}

Çalışma çerçevesinde ele alınan ilk örnek Hüsrev Paşa'nın Bağdat Seferi’ydi. Bu sefer esnasında bölgesindeki konar-göçer cemaatlere ordunun ihtiyacı olan develerin temini için emirler gönderilmişti. Tıpkı koyun temininde olduğu gibi deve talepleri de hem vergi mükellefiyeti çerçevesinde, hem de satın alım yoluyla gerçekleşmişti. Bu çerçevede 1628-9 (H.1038) y1lında ilk talepler ilgili görevlilere iletilmiş, tahsil edilen develer ise 1629-30 (H.1039) yılının ilk aylarında orduya ulaştırılmıştı. Nitekim Bozulus Türkmenlerinden 20 katar (120 adet) deve talebinde bulunulmuş, istenilen develerin 78 adedinin teslimi sağlanmış, 42 adet ise bakiye kalmıştı. Anlaşılan talep edilen devenin \%65'inin tahsili sağlanmıştı. Bakiye kalan develerin her biri içinse 100 kuruş bedel biçilerek, 4.200 kuruş istenmişti ${ }^{55}$.

Bununla beraber avarız mukabilinde talep edilen nakdî deve bedellerinin 1630-31 (H.1040) yılına gelindiğinde henüz tahsil edilemediği anlaşılmaktaydı. Öyle ki Bozulus ve Danişmendlü Türkmenlerinden sürsat ve avarız tahsilinde görevli Mehmet'e gönderilen 8 Temmuz 1631 (8 Zihicce 1040) tarihli hükümde, 1628-9 (H.1038) yılına ait, 1629-30 (H.1039) y1lında talep edilen deve bedellerinin henüz toplanamadığı belirtilmiş ve görevliden ilgili bedellerin tahsil edilmesi istenmişti. Bunun yanında hem Bozulus Türkmenlerinden hem de Danişmendlü Türkmenlerinden avarız yükümlülügü karşılığında yeni aynî deve talepleri de yapılmıştı. Nitekim ilgili vergilerin toplanması işiyle görevlendirilmiş Mehmet’ten 1629-30 (H.1039) ve 1630-31 (H.1040) senelerinde avarız çerçevesinde, Bozulus Türkmenlerinden toplamda 46 katar (276 adet) ve Danişmendlü Türkmenlerinden 10 katar (60 adet) devenin (koşun ve yük takımlarıyla beraber) aynî olarak tahsil edilmesini istemişti ${ }^{56}$. Görüldüğü üzere 1628-9 (H.1038) senesinde avarız mukabilinde tarh edilen deve miktarı, tahsil oranı yüksek olmamasına karşın,

\footnotetext{
53 BOA, MAD. 3443, 189.

54 Orhonlu, Osmanlı Imparatorluğunda Aşiretlerin İskânı,20-21; Usta, “Celâliliğin Türkmen Cephesi: 17.Yüzy1l Anadolu Kırsalında Türkmen Voyvodası ve Türkmenler”, 51-53; Düzbakar, "Hüdavendigar Sahasında KonarGöçerler”, 67-68; Gülten, XVI. Yüzyılda Batı Anadolu’da Yörükler, 58-60.

55 BOA, D.MKF. 27441, 61.

56 BOA, MAD. 8475, 28.
} 
artarak devam etmişti. Bu artış Bozulus Türkmen Cemaati'nin avarız vergisi dâhilinde ele alındığında \% 15 civarında gerçekleşmişti. Lakin 1630-31 (H.1040) yılı kayıtlarına bakıldığında, yine avarız çerçevesinde Bozulus Cemaati'ne bağlı Türkmenlerden deve tahsilinde güçlük çekildiği anlaşılmaktaydı. Bu çerçevede Bozulus'a bağlı cemaatlerden olan Acurlu, Avşar, İnallu, Harbendelü ${ }^{57}$ cemaatlerinin kethüdalarına 21 Temmuz 1631 (21 Zilhicce 1040) tarihinde gönderilen hükümden anlaşılan, avarız mukabilinde adı geçen cemaatler 5 katar (30 adet) deve ile mükellef kılınmış, ancak yükümlülüklerini yerine getirmekte zorlanmışlardı. Nitekim zikredilen Bozulus cemaatlerinin reayası durumu arz etmesinin akabinde, deve tahsilinde küçük bir iyileştirme yapılması ilgili görevlilerden istenmişti. Buna göre istenilen develerin yüklü olarak yani koşun ve yük takımlarıyla değil, çıplak olarak tahsil edilmesi emredilmişti ${ }^{58}$.

Tüm bunların yanında, Hüsrev Paşa'nın Bağdat Seferi çerçevesinde konar-göçer cemaatlerden iştira mukabilinde de deve talep edilmiş, talep edilen develerin temini sürecinde de güçlükler yaşanmıştı. Bozulus Voyvodası Mehmet'e 8 Temmuz 1631 (8 Zilhicce 1040) senesinde gönderilen hükümde, Bozulus Mukataası'nın 1630-31 (H.1040) yılı gelirleri kullanılarak 60 katar (360 adet) yüklü devenin satın alınması istenmişti. Ancak, tekrar eden iştira taleplerine karşın istenilen develer satın alınıp orduya gönderilememişti. Başarısız olan bu iştira isteği sonrasında yetkililer, deve temini için kullanılması belirtilen Bozulus Mukataası gelirlerinin Ordu-yı Hümayun hazinesine gönderilmesini talep etmişlerdi ${ }^{59}$. Bu başarısız girişimlere rağmen Hüsrev Paşa’nın Bağdat Seferi'nin sonlarında yeni deve talepleri devam etmişti. Nitekim 2 Ağustos 1631 (4 Muharrem 1041) tarihinde Yeni-il Voyvodası'na gönderilmiş bir belgeden anlaşıldığı kadarıyla, iştira bedeli ilgili cemaatin mukataa gelirlerinden sağlanmak üzere, Yeni-il Türkmenlerinden 80 katar (480 adet) yüklü devenin satın alınması istenmişti ${ }^{60}$.

Belgelerden anlaşıldığı kadarıyla Hüsrev Paşa’nın Bağdat Seferi’nde, başta Bozulus Türkmenlerinden olmak üzere ordu için tedarik edilmesi planlanan develerin tahsil işi çok da başarılı değildi. Tüm bunlar devlerin tahsil süreciyle ilgili akıllara farklı soruları da getirmekteydi. Nitekim bu soruların başında, deve ihtiyacının karşılanması adına bahsedilen Türkmen cemaatleri acaba fazla mı zorlanmıştı? Bunun cevabını verebilmek için önceki seferlerde Türkmen cemaatlerinden talep edilen deve adedine ve ilgili dönemde sahip oldukları tahmini deve sayısına bakmak gerekmektedir. İfade edildiği üzere Bozulus Türkmenlerinden 1629-30 (H.1039) ve 1630-31 (H.1040) yılında her bir sene için avarız mukabilinde istenilen deve sayısı 23 katar, yani 138 adettir. Yine 1630-31 (H.1040) senesi için iştira yapılması istenilen deve sayısı 60 katar, yani 360 adet deveydi. Belgelerden tespit edildiği kadarıyla Hüsrev Paşa'nın Bağdat Seferi mukabilinde bir sene için talep edilen miktar 498 adet deveden ibaretti. Bununla birlikte III. Murat devrinde 1585 tarihinde düzenlenen doğu seferinde Bozulus Türkmenlerinden belirtilen yıl için 1500 adet deve

57 İlgili Bozulus cemaatleri ile ilgili bkz. Gündüz, Anadolu'da Türkmen Aşiretleri, 110, 115-117, 140, 143.

58 BOA, MAD. 8475, 37.

59 BOA, MAD. 8475, 27.

60 BOA, MAD. 8475, 55. 
talep edilmişti ${ }^{61}$. Bu rakam Hüsrev Paşa'nın seferi esnasında bir yıl çerçevesinde istenilen deve miktarından çok üzerindeydi. Verilen örnekten yola çıkarak Hüsrev Paşa’nın Bağdat Seferi’nde ilgili cemaate mutat olandan fazla bir deve talebi yapılmadığını söyleyebiliriz.

Bunun yanında XVII. yüzyılda Bozulus Cemaati'nin sahip olduğu deve miktarına bakacak olursak, Bozulus Türkmenleri 1653-4 (H.1064) tarihinde 4.273 adet deveye sahipti ${ }^{62}$. Nitekim bu miktar üzerinden bir hesaplama yapacak olursak, Hüsrev Paşa'nın organize ettiği sefer dâhilinde bir sene içerisinde talep edilen deve miktarı sahip oldukları deve adedinin \% 12 'si civarındaydı. Bu miktarın vergi mukabilinde bedelsiz istenen kısmı ise sadece $\% 3$ oranındaydı. Benzer oran Danişmendlü Türkmenlerinden avarız çerçevesinde alınan deve rakamlarında da göze çarpmaktaydı. Öyle ki XVII. yüzyılın ortalarında Danişmendlü Türkmenlerinin sahip olduğu deve 1.250 civarındayd ${ }^{63}$. Hüsrev Paşa'nın Bağdat Seferi esnasında her sene için istenen deve miktarı 30 adet, yani ilgili rakam üzerinden hesap yapılacak olursa sahip oldukları develerin \%2'si vergi kabilinde bedelsiz istenmişti. Anlaşılacağı üzere gerek Bozulus gerekse Danişmendlü Türkmenlerinden talep edilen deve miktarı abartılı rakamlardan oluşmamıştı. Arzın karşılanmasındaki karşılaşılan güçlük başka nedenler sebebiyle yaşanmış olmalıydı.

\subsection{Revan Seferi’nde Deve Temini ve Taşımacılık Hususunda Konar-Göçerlerin Üstlendikleri Rol}

1635 Revan Seferi esnasında da en yaygın kullanılan yük hayvanı deveydi. Nitekim sadece sefer esnasında mirî deve olarak ifade edilen ve Kapıkulu askerinin ihtiyacı çerçevesinde kullanılmış olan deve sayısı yaklaşık 10.000 adeddi. Revan Seferi için istenilen develerin hepsi Anadolu ve çevresindeki eyaletlerden, bir başka ifadeyle sefer bölgesindeki konar-göçer tebaadan vergi karşılığ 1 ya da satın alma yoluyla temin edilip, orduya dâhil edilmişti ${ }^{64}$.

1635 Revan Seferi'nin ihtiyaçlarını karşılamak üzere, kayda değer miktarda deve talep edilen cemaatlerden birisi Bozulus cemaatiydi. Henüz Padişah sefer yürüyüşüne başlamadığ 1 29 Ocak 1635 (10 Şaban 1044) tarihinde Bozulus Voyvodası Mehmet'e, seferde kullanılmak üzere deve temini için bir emir gönderilmiş ve Bozulus Türkmen Cemaati’nden 50 katar (300 adet) devenin tedarik edilmesi istenmişti. Bozulus Voyvodası'na temin edilecek develerin, yol gitmeye ve yük taşımaya elverişli, 6 ya da 7 yaşlarında, güçlü kuvvetli hayvanların olması gerektiği vurgulanmış ve ayrıca voyvodadan develerin tam teçhizatıyla (raht ve gırarları ile) teslim etmesi talep edilmişti. Ne var ki Bozulus Türkmenlerinden temin edilmesi planlanan develerin hepsi satın alma yöntemiyle sağlanmamıştı. Öyle ki 50 katar (300 adet) devenin 20 katarı (120 adedi) avarız vergisine karşılık olarak bedel ödenmeden, 30 katarı (180 adedi) ise Bozulus Hassı gelirleri kullanılarak, iştira yoluyla temin edilmişti ${ }^{65}$. Bozulus Cemaati'nden farklı

61 Oğuzhan Yüce, 59 Numaralı Mühimme Defterinin Özetli Transkripsiyonu ve Değerlendirmesi (Yüksek Lisans Tezi, Atatürk Üniversitesi Sosyal Bilimler Enstitüsü, 2007), 139; Gündüz, Anadolu'da Türkmen Aşiretleri, 59.

62 Gündüz, Anadolu'da Türkmen Aşiretleri, 59.

63 Gündüz, XVII. ve XVIII. Yüzyllarda Danişmendli Türkmenleri, 68.

64 Polat, IV. Murat'ın Revan Seferi Organizasyonu, 87.

65 BOA, MAD. 7275, 3-6; Polat, IV. Murat'ın Revan Seferi Organizasyonu, 84. 
yöntemlerle talep edilen develerin tamamının tedarik edilerek, Revan Seferi'nde kullanılmak üzere, kışlakta bulunan diğer develerle birlikte görevlilere teslim edildiği anlaşılmaktayd ${ }^{66}$. Ne var ki tüm bu süreçte dikkati çeken bir başka husus mevcuttu. Bu da yaklaşık beş yıl önce Hüsrev Paşa'nın Bağdat Seferi'nde aynı cemaatten deve temini girişimlerinin çok başarılı olamamasına rağmen, Revan Seferi’nde daha başarılı bir tedarik sürecinin yaşanmış olmasıydı. İki sefer arasında zamanın kısa olmasına karşın, tedarik sürecindeki bu başarının ardında pek çok neden mevcuttu. Nitekim bu nedenlerin en kayda değer olanlarından birisi, IV. Murat'ın ve ona sadık devlet erkânının yönetimdeki otoritesinin artmış olmasıydı. Bir diğer nedense, Revan Seferi'nde ilgili cemaatten bir yıl içerisinde talep edilen deve miktarının ciddi oranda düşürülmesiydi. Hatırlanacağı üzere Hüsrev Paşa'nın Bağdat Seferi'nde Bozulus Cemaati'nden vergi ve iştira çerçevesinde 498 adet deve talep edilmişti. Revan Seferi'nde ise ilgili cemaatten 300 adet deve, yani sahip oldukları deve miktarının \%7'sine karşılık gelen bir miktar talep edilmişti. Anlaşılacağı üzere önceki sefer sürecinde yaşananlar, bir sonraki seferin planlanmasında önemli verileri/deneyimleri oluşturmuş, talepler bu doğrultuda şekillenmişti.

Revan Seferi'nin ilerleyen süreçlerinde de konar-göçer cemaatlerden deve talepleri devam etmişti. Öyle ki Maraş Beylerbeyi Beşiroğlu Bekir Paşa’ya, 23 Kasım 1635 (12 Cemâziyelevvel 1045) tarihinde gönderilen belgede, 13 katar (78 adet) devenin iştira yoluyla tedarik edilmesi emredilmişti. İştira edilecek develer için her bir katarına rehberiyle birlikte 380 kuruş, İfraz-1 Zulkadriyye Mukataası'nın 1636-7 (H. 1046) senesi gelirinden verilmesi istenmişti. Aynı tarihte benzer bir hüküm Yeni-il ve Türkmen-i Halep Voyvodası Mustafa’ya gönderilmiş ve 12 katar (72 adet) deve talebinde bulunulmuştu ${ }^{67}$. Ordu için deve talebi 1635-6 (H. 1045) senesinin sonlarında da devam etmişti. Öyle ki, Trablus Kadısı'na ve Defterdarı'na yazılan 21 Mayıs 1636 (15 Zilhicce 1045) tarihli hükümde, Seluriye Türkmenlerinden 8 katar (48 adet) deve iştira edilmesi emredilmişti. Satın alınan develerin finansmanı, Trablusşam Hazinesi’ne bağlı Seluriye Türkmen haslarından sağlanmıştı. Hama Sancakbeyi’nden de, aynı tarihte masrafları Hama Mukataası'ndan verilmek üzere, 20 katar (120 adet) deve satın alarak orduya ulaştırması istenmişti ${ }^{68}$. 24 Ekim 1635 (12 Cemâziyelevvel 1045) tarihli bir başka hükümde, Mamalu Taifesi'nden, 1636-7 (H. 1046) sürsat vergisine karşılık olarak, 13 katar (78 adet) deve talep edilmişti ${ }^{69}$. Bunların dışında tarih ve miktar net bir şekilde belirtilmemekle birlikte Danişmendlü Türkmenlerinden de avarız bedeli karşılığı sefer için deve istenmişti ${ }^{70}$. Ayrıca Borlu, Viranşehir, Gerede ve Ankara çevresinde yaşayan Türkmenlerden de 50 katar (300 adet) deve talep edilmişti ${ }^{71}$.

66 Polat, IV. Murat'ın Revan Seferi Organizasyonu, 82.

67 BOA, MAD. 7392, 3.

68 BOA, MAD. 3458, 148.

69 BOA, MAD. 7392, 4.

70 Cumhurbaşkanlığı Devlet Arşivleri Başkanlığı Osmanlı Arşivi (BOA), Bab-1 Defteri, Mevkufat Kalemi Dosya Tasnifi (D.MKF) 13/193.

71 BOA, D.MKF. 17/115; Polat, IV. Murat'in Revan Seferi Organizasyonu, 83-84. 
İncelenen kayıtlarda anlaşıldığı kadarıyla, konar-göçer cemaatler Revan Seferi esnasında deve temini dışında taşımacılık alanında başka roller de üstlenmişlerdi. Osmanlı Devleti’nde bir ücret karşılığı yük hayvanları ile taşımacılık işini yapan kimselere de mekkâri ya da mekkâreci denilirdi. XVII. yüzyıldan itibaren Osmanlı Devleti’nde taşıma işiyle uğraşan deveci, katırcı gibi zümreler esnaf teşekkülleri haline gelmiş ve "mekkâreci”, "mekkârici”, "kiracı” isimlerini kullanarak taşımacılık işini yürütmüşlerdi ${ }^{72}$. Mekkâre teşkilatı çerçevesinde taşımacılık işini yürüten tebaa ise büyük ölçüde bu hayvanlara sahip olan ve yetiştiren konar-göçer aşiret mensuplarıydı. Öyle ki Revan Seferi sürecinde mekkâreciler her türden yükü nakletmişlerdi. Mesela Karaman'dan 29 Kasım 1634'de (8 Cemâziyelâhir 1044) 1.000 kantar (56.449kg) $)^{73}$ güherçile, 12 Ocak 1635'de (23 Recep 1044) 1.000 kantar (56.449 kg) barut ve 2 Mart 1636 (24 Ramazan 1045) tarihinde 800 kantar $(45.159 \mathrm{~kg})$ güherçilenin nakli kiralanan mekkârelerle yapılmıştı. Yine 7 Mart 1635 (18 Ramazan 1044) tarihli bir kayıtta, Halep'te bulunan 2.000 kantar $(112.898 \mathrm{~kg})$ barut ve bir miktar top mermisinin Erzurum'a kiralanan mekkâre deve ve katırları ile gönderilmesi istenmişti. Belgede kaç deve ve katırın bu taşıma işinde kullanılacağı belirtilmemişti. Bununla beraber taşıma ücretinin Halep Hazinesi'ne dâhil edilen 8.000 kuruşluk bir gelirden verileceği belirtilmişti ${ }^{74}$.

Bununla beraber, Revan Seferi esnasında, mekkârelerin taşıdığı barut ile ilgili en ciddi organizasyonlardan biri, 21 Mayıs 1636 (15 Zilhicce 1045) tarihinde gerçekleşmişti. Bu taşıma işini organize etmek için ise Türkmen-i Halep ve Yeni-il Voyvodası Mustafa görevlendirilmişti. Nitekim Voyvoda Mustafa'dan istenen ilk iş, 3.000 kantar $(169.347 \mathrm{~kg})$ barutun taşınması için 700 adet deve temin etmesiydi. Türkmen-i Halep ve Yeni-il Türkmenlerinden toplanacak bu develer için her bir katarına 16 kuruş ödeme yapılması kararlaştırılmıştı. Kiralanan mekkârelere belirtilen ücret yine yerel hazinelerin gelirlerinden verilecekti ${ }^{75}$.

Revan Seferi'nde ordu içerisinde mekkârecilerin yaptığı kayda değer bir diğer nakliyat, kuşatmanın hemen öncesinde Erzurum ile Revan arasında yapılan taşımacılıktı. Buna göre 1635 Temmuz ayının başlarında Hüseyin Ağa vasıtasıyla gerçekleştirilen taşımacılık işinde 9.509 adet bargir ve 3.600 adet deve kiralanmıştı. Kiralanan hayvanlarla başta barut, kurşun, kürek, külenk, çuval gibi seferde ve kuşatmada kullanılacak bir takım askerî mühimmat taşınacaktı. Hayvanların ücretleri karşılığı ise toplam 62.720 kuruş, yani 6.272 .000 akçe ödenmişti. Bu rakamın 36.720 kuruşu bargirlere, 26.000 kuruşu develere kira bedeli olarak verilmişti ve bu ücret içerisinde sürücülere ödenen para dâhil değildi ${ }^{76}$. Rakamlardan anlaşıldığı kadarıyla

72 Ümit Ekin, Osmanlı Dönemi ulaşım Teknolojisi ve Örgütlenmesi Üzerine Bir Araştırma: Mekkârî Esnafinın Tarihi, Basılmamış (Yüksek Lisans Tezi, Ankara Üniversitesi Sosyal Bilimler Enstitüsü, 1996), 37; Ömer İşbilir, "Mekkâre", TDV İslam Ansiklopedisi, c. 28, (Ankara: TDV Yayınları, 2003), 554.

73 Cengiz Kallek, “Kantar”, TDV Íslam Ansiklopedisi, c. 24, (Ankara: TDV Yayınlar1, 2001), 319.

74 BOA, MAD. 6375, 75; Cumhurbaşkanlığı Devlet Arșivleri Başkanlığı Osmanlı Arşivi (BOA), Mühimme Defteri Zeyli (MD ZYL) 9, 162, h.484; BOA, MAD. 3458, 64; BOA, MAD. 3458, 82; BOA, MD ZYL. 9, 112, h.348; Polat, IV. Murat'in Revan Seferi Organizasyonu, 93-94.

75 BOA, MAD. 3458, 149; Polat, IV. Murat'in Revan Seferi Organizasyonu, 94-95.

76 Cumhurbaşkanlığı Devlet Arşivleri Başkanlığı Osmanlı Arşivi (BOA), Bab-1 Defteri, Büyük Ruznamçe Kalemi (D.BRZ) 20690, 113; Polat, IV. Murat'ın Revan Seferi Organizasyonu, 96. 
Erzurum-Revan arası kiralanan her bir bargire 3,86 kuruş ve her bir deve için 7,22 kuruş ödenmişti. Tüm bu örneklerin işaret ettiği üzere, konar-göçer cemaatler Revan Seferi sürecinde gerek orduya mirî hayvan temini hususunda, gerekse mekkâre teşkilatı çerçevesinde parayla yaptıkları nakliyatla sefere önemli katkılar sağlamışlardı. Özellikle, konar-göçer gruplar ücret karşılı̆̆ yürüttükleri taşımacılık sayesinde, savaşın sağladığı ekonomik firsatlardan olumlu anlamda faydalanmışlardı.

\subsection{Bağdat Seferi’nde Deve Temini ve Taşımacılık Hususunda Konar-Göçerlerin Üstlendikleri Rol}

Hiç şüphesiz IV. Murat iktidarının en önemli askeri faaliyetlerinden birisi Bağdat Seferi’ydi. Bu seferin başarılı olması için hiçbir şeyden kaçınılmamış muazzam bir hazırlık yapılmıştı. Bağdat Seferi sürecinde konar-göçer cemaatler, Revan Seferi örneğinde olduğu gibi, ordunun mirî deve ihtiyacının karşılanması ve ordu için gerekli savaş mühimmatının ve askerin iaşesi için gerekli erzakın taşınması görevlerini üstlenmişlerdi ${ }^{77}$.

Özellikle seferin ilk merhalesinde kayda geçmiş bir belgeden, ordunun ihtiyaçları için Yeni-il ve Mamalu cemaatlerinden 203,5 katar (1.221 adet) devenin istendiği anlaşılmaktadır. Buna göre, bu develerin 184 katarı (1.104 adedi) Yeni-il Türkmenlerinden 1636-7 (H. 1046) senesinde talep edilmişti. İştira çerçevesinde sağlanacak develerin ücretleriyse yine adı geçen cemaatin mukataa gelirlerinden karşılanacaktı. Bunun yanında 30 Mart 1638 (14 Zilkade 1047) tarihinde, Yeni-il Türkmenlerinden talep edilen develerin 154 katarının (924 adedinin) Okçubaşı Mustafa nezaretinde tahsil edilip, orduya teslim edilmişti. Mamalu Cemaati'nden 1637-8 (H. 1047) senesinde talep edilen, 19,5 katar (117 adet) devenin ise tesliminin henüz yapılmadığı belirtilmiş ve Yeni-il Cemaati'nden bakiye kalan develerle beraber toplamda 49,5 katar (297 adet) devenin bir an evvel temin edilip orduya ulaştırılması emredilmişti ${ }^{78}$.

1638 Bağdat Seferi esnasında aynı tarihte kayda geçmiş bir başka belgeden anlaşılan, Bozulus ve Danişmendlü Türkmenlerinden yüklü miktarda deve talebinde bulunulmuştu. Buna göre Bozulus ve Danişmendlü Voyvodası Minnet'ten, ilgili cemaatlerin 1636-7 (H. 1046) senesi mukataa gelirleri kullanılarak, 83 katar (498 adet) ve Hazine-i Amire'den gönderilen para ile 41 katar (246 adet) deve satın alması istenmiş, buna ek olarak Bozulus ve Danişmendlü avarızı karşılığında 26 katar (156 adet) devenin temin edilip orduya gönderilmesi talep edilmişti. Ne var ki 30 Mart 1638 (14 Zilkaide 1047) tarihli kayıttan, talep edilen 900 adet devenin ancak 400 adedinin, yani \%44'ünün tesliminin sağlandığg anlaşılmaktadır. Bunun üzerine Voyvoda Minnet’ten geriye kalan develerin tedarik edilip gönderilmesi istenmişti ${ }^{79}$.

Bağdat Seferi sürecinde, hem Bozulus ve Danişmendlü Türkmenlerinden, hem de bu

77 Bağdat Seferi'nde konar-göçer ve diğer taifelerden genel hatlarıla deve tedariki için bkz. Ünal, IV. Murat ve Bağdat Seferi, 58; Ünal, "Savaşa Çıkan Osmanlı Ordusunda Lojistik İşleri” 732; Yans, "IV. Murad Devrinde Osmanll-Safevî Münasebetleri”, 174; Küpeli, Osmanll-Safevi Münasebetleri”, 242.

78 BOA, MAD. 3443, 100.

79 BOA, MAD. 3443, 98. 
cemaatlerin voyvodalığını üstlenen Minnet’ten ordunun ihtiyacı için gerekli deve talepleri sürmüştü. Bu taleplerin bir kısmı yeni arzlar olmakla beraber, diğer kısmı ise karşılanmamış önceki isteklerdi. Öyle ki, 27 Nisan 1638 (12 Zilhicce 1047) tarihinde, Minnet’ten 1636-7 (H. 1046) ve 1637-8 (H. 1047) tarihinde taahhüt ettiği, ancak henüz göndermediği 89 katar ve 2 adet (538 adet) devenin bir an evvel göndermesi istenmişti ${ }^{80}$. Hükmün ayrıntılarında dikkat çeken noktaysa, 1636-7 (H. 1046) tarihinde bakiye kalan deve sayısının sadece 6 katar (36 adet) olmasıydı. Anlaşılan, yukarıda ifade edilen 1636-7 (H. 1046) senesi mukataa gelirleri kullanılarak temin edilmesi istenmiş 83 katar (498 adet) devenin büyük kısmı tedarik edilip orduya gönderilmişti. Nitekim bu durum, deve taleplerinde gecikmeler olsa dahi görevlilerin durumu sürekli takip ettiğini ve bir şekilde savaş boyunca deve üreticisi olan konar-göçerlerin ilgili talepleri karşılamaya çalıştıklarını göstermektedir. Öyle ki bunu destekler nitelikte 3 Mayıs 1638 (18 Zilhicce 1047) tarihinde Minnet'e gönderilmiş bir başka hükümde, 1638-9 (H. 1048) yılı Bozulus mukataa gelirleri kullanılarak 40 katar (200 adet) devenin satın alınıp orduya sevki istenmişti ${ }^{81}$.

1635 Revan Seferi'nde olduğu gibi 1638 Bağdat Seferi'nde de konar-göçer cemaatler, deve temini yanında, bizzat develeriyle yaptıkları taşımacılık ile sefere önemli hizmetlerde bulunmuşlardı. Özellikle Birecik'te toplanan askerî mühimmat ve iaşe maddeleri konar-göçer cemaatlerden kiralanan develer vasıtasıyla Bağdat'a kadar taşınmıştı. Bu çerçevede Yeni-il ve Türkmen-i Halep cemaatleri kendi develeri ile taşımacılık çerçevesinde ön plana çıkmış konar-göçer gruplardan biriydi. Nitekim bu süreçte ilgili cemaat yöneticilerine Bağdat Seferi esnasında yapılacak olan taşımacılık işini de ortaya koyacak pek çok hüküm gönderilmişti. Buna göre, taşımacılık için talep edilen develer sürücüleriyle birlikte orduya Birecik’te dâhil olacaklardı. Birecik’te depolanan askerî mühimmatı ve iaşe maddelerini, ordu ile beraber hareket ederek Bağdat'a kadar taşıyacaklardı. Bağdat'a ulaştıklarında taşıma görevini üstlenen kişilere icazet verilecek ve görevleri son bulacaktı. Yeni-il ve Türkmen-i Halep cemaatinden talep edilen deve 2.000 adetti. Taşıma görevini üstlenecek develerin ve sürücülerin temini için cemaat kethüdası, bölükbaşı ve iş erleri görevlendirilmişti. Taşıma karşılığında her bir deve için ödenecek tutar ise 25 kuruş olarak belirlenmişti. Ayrıca deve ile sürücülerin 1638 Ağustosunun başında (1048 Rebî‘ülevvelinin sonunda) Birecik’te olması istenmişti ${ }^{82}$. Benzer hükümler deve sahibi olan diğer konar-göçer cemaatlere de gönderilmişti. Mesela

80 BOA, MAD. 3443, 243.

81 BOA, MAD 3443, 241. Bağdat Seferi çerçevesinde talep edilen develerin takibiyle ilgili pek çok hüküm bulunmaktadır. Mesela Tokat Defterdarı'na gönderilen bir hükümde, 1636-7 (H. 1046) tarihi gelirleri kullanılarak talep edilen 45 katar (270 adet) deveden, bakiye kalan 25 katarının (150 adet) teslimi istenmiştir. Bir başka hükümde ise Halep Defterdarı'ndan yine bakiye kalan 20 katar (120 adet) deve talep edilmiştir. Bkz. BOA, MAD. 3443, 99.

82 BOA, MAD. 2841, 40, 43, 99. Bu süreçte Yeni-il ve Halep Türkmenlerinden talep edilen develerin 730 adedinin Bilecik-Bağdat arasında deve başına 25 kuruş ile taşımacılık görevinde bulunduğuna dair bkz. İlhan Şahin, "1638 Bağdad Seferinde Zahire Nakline Memûr Edilen Yeni-il ve Halep Türkmenleri”, 227-234; Şahin'in çalışmasında belirttiği bu 730 adet deve, Yeni-il ve Halep Türkmen kadılarının sorumluluğunda, Yusuf ve Mustafa isimli görevliler mübaşeretinde gönderilen develerdi. 
Halep Kadısı'na ve Defterdarı'na gönderilen hükümde, Akçakoyunlu Türkmenlerinden yük taşımak için 2.000 adet deve talep edilmişti. Görevlilere Birecik’ten Bağdat'a zahire nakli için kullanılacak develerin çuvallarıyla beraber hazır edilmesi ve orduyla beraber hareket edecek develerin her birine 25 kuruş verilmesi belirtilmişti ${ }^{83}$. Bozulus Türkmenlerinden ise 900 adet deve yük taşımak için talep edilmişti. Bozulus Kadısı'na gönderilen hükümde, taşımacılık için gönderilecek kişilere kefiller belirlenmesi ve ilgili kişilerin develerle beraber 1638 Ağustosunun başında (1048 Rebî‘ülevvelinin sonunda) Birecik’te toplanması emredilmişti. Her biri deveye verilecek 25 kuruş ücretin 10.000 kuruşu Hazine-i Amire'den, geri kalanı ise Bozulus Mukataası gelirlerinden verilmesi belirtilmişti ${ }^{84}$. 19 Ağustos 1638 (8 Rebî‘ülâhır 1048) tarihinde Danişmendlü Kadısı'na ve Voyvodası'na gönderilen emirde, aynı şartlarla 600 deve ve deveci talep edilmişti ${ }^{85}$. Aynı çerçevede gönderilen diğer hükümlerde, Birecik’ten Bağdat'a zahire nakletmek için Lekvanik ve Mamalu cemaatlerinden 1.500 deve, Rişvan Aşireti'nden 200 deve, Millü ve Şikaki aşiretlerinden 2.000 deve, Rakka Eyaleti’ndeki konar-göçer halktan 600 deve, Mardin ve çevresindeki aşiretlerden 2.500 deve, Malatya ve çevresindeki aşiretlerden 1.500 deve, sürücüleriyle beraber talep edilmişti ${ }^{86}$.

Konar-göçer tebaadan ordunun Bağdat'a yürüyüşü esnasında 13.800 adet devenin kiralanması istenmişti. Lakin bu talebin karşılanmasında birtakım sorunlar da yaşanmıştı. Mesela Danişmendlü Türkmenlerinden zahire nakli için istenilen 600 adet devenin 347 adedi gelmişti. Nitekim ordunun dönüşü esnasında 13 Mayıs 1639 (10 Muharrem 1049) tarihinde Danişmendlü Türkmenlerinin Voyvodası'na ve Kadısı'na gönderilen hükümde, gelmeyen fakat taşıma ücreti tahsis edilmiş deve sahiplerine verilmiş olan paraların geri alınması istenmişti ${ }^{87}$. Daha ilginç bir örnek Rişvan Aşireti’nin gönderdiği deve ve devecilerin taşıma işinde yaşanmıştı. Hatırlanacağ 1 üzere, Bağdat'a zahire nakli için Rişvan Aşireti'nden 200 adet deve talep edilmişti. Nitekim Rişvan Kadısı'na 19 Şubat 1639 (15 Şevval 1048) tarihinde gönderilen hükümden anlaşıldığ 1 üzere, 200 adet devenin yük taşımak amacıyla Birecik’e ulaşmıştı. Birecik’e ulaşan her bir deveye 10 İstanbul kilesi arpa yüklenmiş ve taşıma ücreti olan 25 kuruş verilmişti. Ne var ki 960 kile arpa ilgili cemaate ait 96 adet deve ile orduya teslim edilmişken, 104 devenin taşıması gereken 1.040 kile arpa orduya ulaşmamıştı. Nitekim ordunun dönüşü esnasında Diyarbakır'da yazılan hükümde Rişvan Kadısı'ndan, bakiye kalan zahirenin her bir kilesi için 1 kâmil kuruş ve her bir deve için ödenen 25 kuruşun, görevini yerine getirmeyen devecilerden alınarak, ordu hazinesine teslimi istenmişti ${ }^{88}$.

Tüm bunların yanında, deve ile yaptırılan taşımacılık zikredilen konar-göçer cemaatlerle

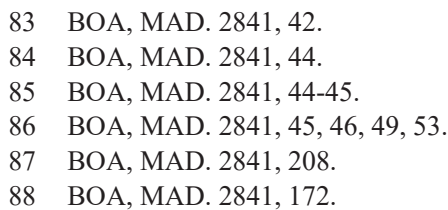


sınırlı kalmamış, deveye sahip olan ve taşımacılık yapan yahut yapabilecek olan tebaadan da yardım alınmıştı. Öyle ki Cizre Sancakbeyi Ramazan’a ve Nusaybin Kadısı'na 25 Eylül 1638 (16 Cemâziyelevvel 1048) tarihinde gönderilen muhtelif hükümler buna delil niteliğindeydi. Buna göre bugün Mardin'in Kızıltepe mevkiinde bulunan Koçhisar'daki mirî ambardan yüklü miktarda zahirenin nakledilmesi için "Arabân” taifesinden 1.200 adet devenin kiralanması istenmişti. Bu çerçevede her bir deveye 11 İstanbul kilesi zahire yüklenecekti ve kira bedeli olarak ise her bir deveye 12 kuruş verilmesi kararlaştırılmıştı. Taşıma işinden birinci derecede sorumlu olan Cizre Beyi Ramazan'a, her bir deve sahibini kefilleriyle beraber deftere kaydetmesi, Koçhisar Ambarı'ndan zahireleri yüklemesi ve taşımacılık işini yapacak kişilere ücretlerini eksiksiz bir biçimde ödemesi emredilmişti ${ }^{89}$.

\section{Sonuç}

Başlangıçta Osmanlı Devleti'nin kuruluşunda en önemli askerî gücünü oluşturan konargöçer cemaatler zaman içerisinde vergisini veren birer tebaaya dönüşmüştü. İstisnalar dışında bu grubun savaşlardaki yeni rolü, sefer organizasyonlarına üretimleri çerçevesinde yaptıkları katkıydı. Nitekim XVII. yüzyılın ilk yarısında birbiri ardına Safevi Devleti'ne karşı düzenlenen sefer organizasyonlarında, sefer bölgesinde bulunan diğer tebaaya olduğu gibi, konar-göçer cemaatlere de yükümlülükler yüklenmişti. Bu yükümlülükler yaşam biçimlerinin bir ürünü olan yetiştirdikleri koyun ve devenin ordunun ihtiyaçları için tedariki ve sahip oldukları yük hayvanlarıyla yaptıkları taşımacılıktı.

XVII. yüzyılın ilk yarısında doğuya yapılan Osmanlı seferlerinde, iaşe organizasyonunun bir parçası olan etin önemli bir kısmı bölgedeki konar-göçer cemaatlerden talep edilen koyunlarla karşılanmak istenmişti. Bu talep sürsat mukabilinde vergi yükümlülüğüyle ve iştira yöntemiyle gerçekleşmişti. Ancak incelenen seferler aynı rakibe ve birbirine yakın zaman diliminde düzenlenmiş olmasına karşın, şartlara ve seferlere göre koyun temininde dalgalanmalar yaşanmıştı. Öncelikle Revan Seferi'ne kıyasla Bağdat seferlerinde konar-göçer tebaadan daha fazla koyun talep edilmişti. Bu durumun muhtemel sebebi daha uzun bir sefer güzergâhına sahip olan Bağdat seferlerinde daha fazla iaşe maddesine ihtiyaç duyulmasıydı. Bununla beraber konar-göçerlerin yaşadığı bölgelere göre talep edilen koyun miktarı değişiklik göstermişti. Revan Seferi'nde Bozulus Türkmenlerinden, Bağdat seferlerinde ise Türkmen-i Halep ve Yeni-il Türkmenleriyle bu seferin önemli merkezlerinden olan Diyarbakır çevresindeki konar-göçer cemaatlerden talep edilen koyun miktarı artmıştı. Bunun yanında konar-göçer grupların bir kısmı mümkün mertebe belirlenen özelliklerde belirlenen satış fiyatıyla "mükellefiyet şeklinde yürütülen iştirayla" koyunlarını satmak istemiyorlardı. Bunun en muhtemel nedeni serbest piyasada daha yüksek bedellerle koyunlarını satabilmeleriydi.

Satın alma sürecinde genellikle cemaat voyvodaları ve kadıları görevlendirilmişti. Özellikle

89 BOA, MAD. 2841, 124. Tüm bu veriler aynı zamanda mesafeye göre ödenen ücretin ve -daha da dikkat çekici tarafi- her bir deveye mesafeye göre yüklenen yükün değiştiğini de göstermektedir. Nitekim Birecik’ten Bağdat'a her bir deveye 10 İstanbul kilesi zahire yüklenirken, Mardin'den Bağdat'a 11 İstanbul kilesi zahire yüklenmişti. 
voyvodaların görevlendirilmesinin nedeni, konar-göçer cemaatlerin mali işlerinin takibini yapıyor olmalarından dolayı bu cemaatlerden nerede, nasıl koyun tedarik edeceklerini bilmeleriydi. Ayrıca bu süreçte voyvodalardan tasarruf ettikleri gelirleri kullanarak satın alma işlemini yürütmeleri de istenmişti. Buradaki temel amaçsa mahsup hesap uygulanarak mali bürokratik işlemlerin kolaylaştırılmasıydı.

Konar-göçer cemaatlerin seferlerde üstlendikleri ikinci kritik görevse deve temini ve taşımacılık hizmetiydi. İncelenen örneklerde, Hüsrev Paşa'nın Bağdat Seferi'nde deve talebinin yüksek olduğu, bu sefere kıyasla Revan Seferi'nde azaldığı, 1638 Bağdat Seferi'ndeyse tekrar artış gösterdiği görülmektedir. Anlaşılan talebin azalması yahut artması, tamamen sefer ihtiyaçları çerçevesinde belirlenmişti. Daha uzun mesafeli olan Bağdat seferleri için daha fazla deve talebi yapılmıştı. Bu nedenle vergi ve satın alma yoluyla talep edilen deve sayısında bariz bir artış mevcuttu. Fakat ihtiyaçlar mukabilinde artan deve talebinin sağlanmasında sıkıntılar yaşanmıştı. İfade edildiği üzere konar-göçer cemaatlerin her bir sene içerisinde sağlayabilecekleri deve miktarı belirliydi ve bu rakamın üzerindeki arzın karşılanması mümkün olmamıştı. Ancak, dönemin seferleri bir yıldan fazla sürdüğünden, talep edilen develer ilgili cemaatlerden takip eden senelerde peyderpey karşılanmaya çalışılmış yahut Hüsrev Paşa'nın organizasyonunda olduğu gibi aynî develer yerine nakdî bedeller alınması yoluna gidilmişti. İncelemelerden anlaşılan sefer esnasında konar-göçer cemaatler vergi yahut satın alma yoluyla deve vermekten ziyade, kendi yük hayvanlarıyla taşıma işini yürütmeye daha meyilliydiler. Muhtemelen sefer ağırlığını bir bedel karşılığı taşımak konar-göçerler için daha karlıydı. Lakin daha gönüllü yaptıkları bu işte dahi talepleri karşılayamadıkları yahut bir takım usulsüzlüklere karıştıkları zamanlar olmuştu.

Konar-göçerler üzerinden tüm bu anlatılanlar, Osmanlı Devleti’nin dönem itibariyle sefer organizasyonlarının kapasitesi hakkında da fikir vermekteydi. Nitekim Osmanlı Devleti'nin XVII. yüzyılda -bir yeri fetih etmesi yahut hâkimiyeti altına alması- düşmanın gücünden, doğal sınırların oluşturduğu engelden veya mesafenin uzaklığından ziyade, kendi öz kaynaklarıyla bu engelleri aşabilme kapasitesiyle ilgiliydi. Osmanlı'nın doğu yahut batıdaki sınırlarının ya da hâkimiyet sahasının belirlenmesinde sefer organizasyon kapasitesi etkili olmuştu. Bu organizasyon kapasitesiyse sefer için gerekli mühimmat ve teçhizat sağlayan tebaasının üretim limitleriyle belirlenmişti.

Hakem Değerlendirmesi: Dış bağımsız.

Çıkar Çatışması: Yazar çıkar çatışması bildirmemiştir.

Finansal Destek: Yazar bu çalışma için finansal destek almadığını beyan etmiştir.

Peer-review: Externally peer-reviewed.

Conflict of Interest: The author has no conflict of interest to declare.

Grant Support: The author declared that this study has received no financial support.

\section{Kaynaklar/References}


Agoston, Gabor. “Savaş”, TDV İslam Ansiklopedisi. 36: 196-200. İstanbul: TDV Yayınları, 2009.

Düzbakar, Ömer. "Hüdavendigar Sahasında Konar-Göçerler”, Uludă̆ Üniversitesi, Fen-Edebiyat Fakültesi Sosyal Bilimler Dergisi 4/1 (2003): 61-74.

Emecen, Feridun. “Kosova Savaşları”, TDV İslam Ansiklopedisi. 26: 221-224. Ankara: TDV Yayınları, 2002.

Emecen, Feridun. Osmanlı Klasik Çă̆ında Savaş. İstanbul: Timaş Yayınları, 2010.

Erdoğan, Meryem Kaçan. II. Viyana Kuşatması. Doktora Tezi, Marmara Üniversitesi Türkiyat Araştırmaları Enstitüsü, 2001.

Ertaş, Mehmet Yaşar. Sultanın Ordusu (Mora Fethi Örneği 1714-1716). İstanbul: Yeditepe Yayınları, 2007.

Finkel, Caroline. Administration of Warfare: The Ottoman Military Campaigns in Hungary, 1593-1606. Wien: 1988.

Gökbilgin, Tayyib. Rumelide Yörükler, Tatarlar ve Evlâd-ı Fâtihân. İstanbul: İstanbul Üniversitesi Edebiyat Fakültesi Yayınları, 1957.

Güçer, Lütfi. XVI-XVII Asırlarda Osmanlı Imparatorluğu'nda Hububat Meselesi ve Hububattan Alınan Vergiler. İstanbul: İstanbul Üniversitesi Yayınları, 1964.

Gülten, Sadullah. “XVI. Yüzyılda Batı Anadolu'da Yörükler”. Doktora Tezi, Gazi Üniversitesi Sosyal Bilimler Enstitüsü, 2008.

Gündüz, Tufan. "Konar-göçer”, TDV İslam Ansiklopedisi. 26: 161-163. İstanbul: TDV Yayınları, 2002.

Gündüz, Tufan. Anadolu'da Türkmen Aşiretleri. İstanbul: Yeditepe Yayınları, 2015.

Gündüz, Tufan. Bozkırın Efendileri-Türkmenler Üzerine Makaleler. İstanbul: Yeditepe Yayınları, 2015.

Gündüz, Tufan. XVII. ve XVIII. Yüzyıllarda Danişmendli Türkmenleri. İstanbul: Yeditepe Yayınları, 2005.

Halaçoğlu, Yusuf. XVIII. Yüzyılda Osmanlı Imparatorluğu'nun İskân Siyaseti ve Aşiretlerin Yerleştirilmesi. Ankara: TTK Yayınları, 2014.

Halaçoğlu, Yusuf. Anadolu'da Aşiretler Cemaatler ve Oymaklar (1453-1650), cilt 1. Ankara: TTK Yayınları, 2009. İnalcık, Halil. "Hüsrev Paşa”, TDV İslam Ansiklopedisi. 19: 37-40. İstanbul: TDV Yayınları, 1999.

İnalcık, Halil. “Osman Gazi’nin İznik (Nicaea) Kuşatması ve Bafeus Savaşı”, Söğüt’ten İstanbul'a Osmanlı Devleti’nin Kuruluşu Üzerine Tartışmalar. Derleyenler Oktay Özel, Mehmet Öz, 301-339, Ankara: İmge Yayınlar1, 2005.

İnalcık, Halil. Kuruluş Dönemi Osmanlı Sultanları. İstanbul: İsam Yayınları, 2010.

İnbaş1, Mehmet. Ukrayna'da Osmanlılar Kaminiçe Seferi ve Organizasyonu (1672). İstanbul: Yeditepe Yayınlar1, 2004.

İşbilir, Ömer. "Mekkâre”, TDV İslam Ansiklopedisi. 28: 554-555. Ankara: TDV Yayınları, 2003.

İşbilir, Ömer. XVII. Yüzyıl Başlarında Şark Seferlerinin İaşe, İkmal ve Lojistik Meseleleri. Doktora Tezi, İstanbul Üniversitesi Sosyal Bilimler Enstitüsü, 1996.

Kallek, Cengiz. “Kantar”, TDV İslam Ansiklopedisi. 24: 317-320. Ankara: TDV Yayınları, 2001.

Küpeli, Özer. Osmanll-Safevi Münasebetleri. İstanbul: Yeditepe Yayınları, 2014.

Orhonlu, Cengiz. Osmanlı Imparatorluğunda Aşiretlerin İskânı. İstanbul: Eren Yayınları, 1987.

Özcan, Abdulkadir. “Akıncı”, TDV İslam Ansiklopedisi. 2: 249-250. İstanbul: TDV Yayınları, 1989. 
Polat, Süleyman. “Osmanlı Sefer Organizasyonunda Pratik Çözümler: 1634-1635 (H. 1044) Tarihlerinde Karahisar-1 Şarki'de "Mükellefiyet Şeklinde Yürütülen İştira” ile Zahire Temini”, Gazi Akademik Bakış IV/8 (2011): 161-174.

Polat, Süleyman. IV. Murat'ın Revan Seferi Organizasyonu ve Stratejisi. Ankara: ATASE Yayınları, 2015.

Saydam, Abdullah “Sultanın Özel Statüye Sahip Tebaası: Konar-Göçerler”, SDÜ Fen Edebiyat Fakültesi Sosyal Bilimler Dergisi 20 (2009): 9-31.

Şahbaz, Davut. XVI. Yüzyılda Ulu Yörük Teşekkülleri (Etrak-ı Büzürk). Doktora Tezi, Ankara Üniversitesi Sosyal Bilimler Enstitüsü, 2018.

Şahin, İlhan. “1638 Bağdad Seferinde Zahire Nakline Memûr Edilen Yeni-il ve Halep Türkmenleri”, İstanbul Üniversitesi Edebiyat Fakültesi Tarih Dergisi 33 (1982): 227-234.

Şahin, İlhan. Osmanlı Döneminde Konar-Göçerler. İstanbul: Eren Yayınları, 2006.

Türkmen, M. Nuri. Kamaniçe Seferinin Lojistik Hazırlıkları. Doktora Tezi, Ankara Üniversitesi Sosyal Bilimler Enstitüsü, 2002.

Usta, Onur. "Celâliliğin Türkmen Cephesi: 17.Yüzyıl Anadolu Kırsalında Türkmen Voyvodası ve Türkmenler” Kebikeç 33 (2012): 49-86.

Ünal, Tahsin. "Savaşa Çıkan Osmanlı Ordusunda Lojistik İşleri -IV. Murad'ın Bağdat Seferi Hazırlıkları-" Türk Kültürü, V/58 (1967): 728-740.

Ünal, Tahsin. IV. Murat ve Băgdat Seferi. İstanbul: Berikan Yayınları, 2001.

Yans, Kerim. IV. Murad Devrinde Osmanlı-Safevî Münasebetleri. Doktora Tezi, İstanbul Üniversitesi Edebiyat Fakültesi Osmanlı Müesseseleri ve Medeniyeti Tarihi Kürsüsü, 1977.

Yıldız, Hakan. 1711 Prut Seferi'nin Lojistik Faaliyetleri. Doktora Tezi, Marmara Üniversitesi Türkiyat Araştırmaları Enstitüsü, 2000.

Yüce, Oğuzhan. 59 Numaralı Mühimme Defterinin Özetli Transkripsiyonu ve Değerlendirmesi. Yüksek Lisans Tezi, Atatürk Üniversitesi Sosyal Bilimler Enstitüsü, 2007.

\section{Arşiv Kaynakları}

Cumhurbaşkanlığg Devlet Arşivleri Başkanlığı Osmanlı Arşivi (BOA). Bab-1 Defteri, Büyük Ruznamçe Kalemi (D.BRZ) 20690, H. 1045 (1635-1636).

Cumhurbaşkanlığı Devlet Arşivleri Başkanlığı Osmanlı Arşivi (BOA). Bâb-1 Defteri, Mevkufat Kalemi Defterleri (D.MKF) 27441, H.1039 (1629-30).

Cumhurbaşkanlığı Devlet Arşivleri Başkanlığı Osmanlı Arşivi (BOA). Bab-1 Defteri, Mevkufat Kalemi Dosya Tasnifi (D.MKF),13/193, H. 1046 (1636-7).

Cumhurbaşkanlığı Devlet Arşivleri Başkanlığı Osmanlı Arşivi (BOA). Bab-1 Defteri, Mevkufat Kalemi Dosya Tasnifi (D.MKF), 17/115, H. 1046 (1636-7).

Cumhurbaşkanlığı Devlet Arşivleri Başkanlığı Osmanlı Arşivi (BOA). Kamil Kepeci Defterleri (KK) 2575, H.1043-44 (1633-35).

Cumhurbaşkanlığ ${ }_{1}$ Devlet Arşivleri Başkanlığ ${ }_{1}$ Osmanlı Arşivi (BOA). Maliyeden Müdevver Defterleri (MAD) 8475 , H.1039 (1629-30).

Cumhurbaşkanlığ 1 Devlet Arşivleri Başkanlığ ${ }_{1}$ Osmanlı Arşivi (BOA). Maliyeden Müdevver Defterleri (MAD) 7275, H. 1044 (1634-1635). 
Cumhurbaşkanlığı Devlet Arşivleri Başkanlığı Osmanlı Arşivi (BOA). Maliyeden Müdevver Defterleri (MAD) 4433, H. 1044 (1634-1635).

Cumhurbaşkanlı̆̆ı Devlet Arşivleri Başkanlığ Osmanlı Arşivi (BOA). Maliyeden Müdevver Defterleri (MAD) 3443, H. 1046-48 (1636-39).

Cumhurbaşkanlığı Devlet Arşivleri Başkanlığı Osmanlı Arşivi (BOA). Maliyeden Müdevver Defterleri (MAD) 2841, H. 1048 (1638-39).

Cumhurbaşkanlı̆̆g Devlet Arşivleri Başkanlığı Osmanlı Arşivi (BOA). Maliyeden Müdevver Defterleri (MAD) 18186, H. 1049 (1639-40).

Cumhurbaşkanlığı Devlet Arşivleri Başkanlığı Osmanlı Arşivi (BOA). Maliyeden Müdevver Defterleri (MAD) 7392, H. 1046 (1636-7).

Cumhurbaşkanlığı Devlet Arşivleri Başkanlığı Osmanlı Arşivi (BOA). Maliyeden Müdevver Defterleri (MAD) 3458, H. 1045 (1635-1636).

Cumhurbaşkanlığı Devlet Arşivleri Başkanlığı Osmanlı Arşivi (BOA). Maliyeden Müdevver Defterleri (MAD) 6375, H. 1044 (1634-1635).

Cumhurbaşkanlığı Devlet Arşivleri Başkanlığı Osmanlı Arşivi (BOA). Mühimme Defteri Zeyli (MD ZYL) 9, H. 1044 (1634-1635).

Topkapı Sarayı Müzesi Arşivi (TSMA). E. 5222-28. 